
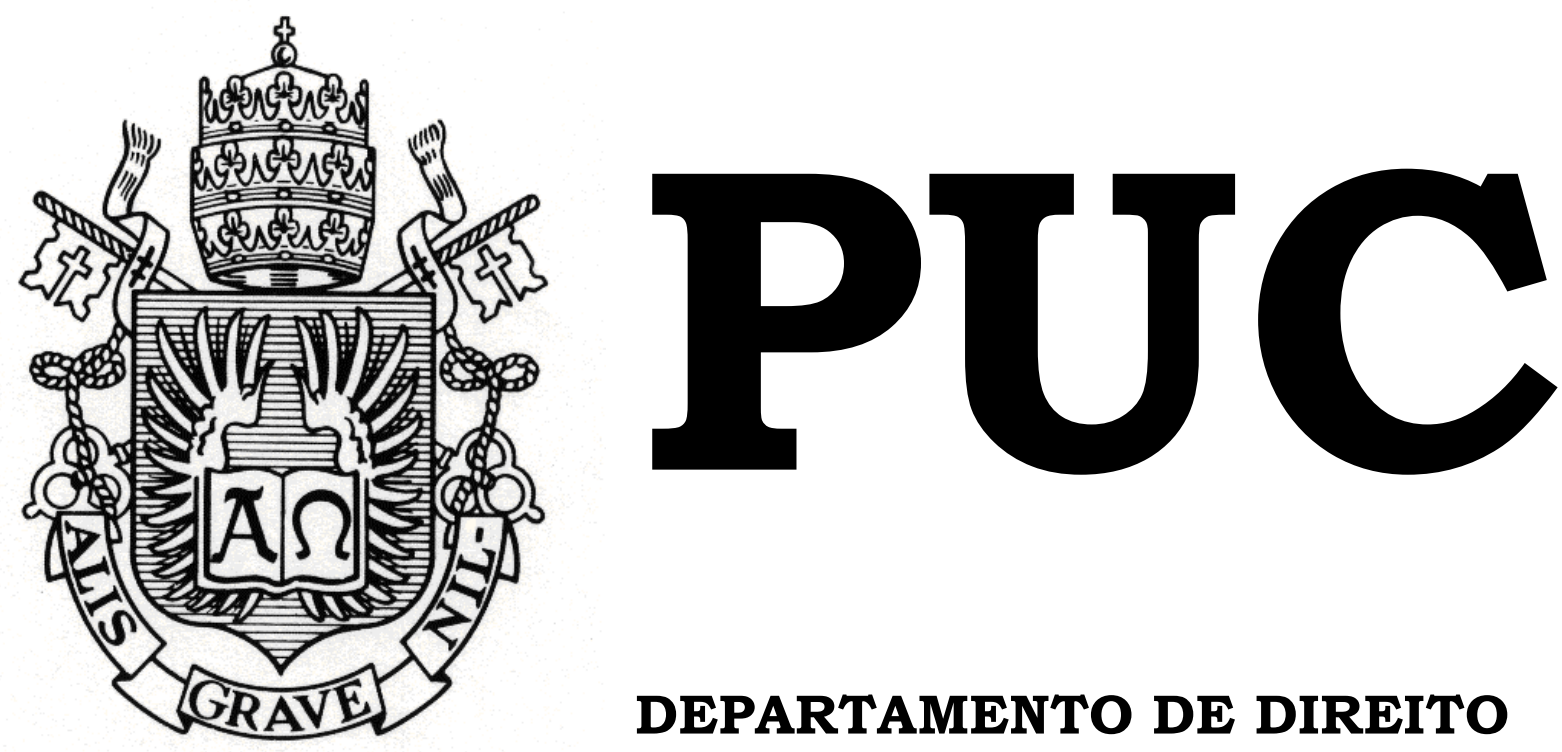

DEPARTAMENTO DE DIREITO

\title{
UMA ANÁLISE DA RESPONSABILIDADE INTERNACIONAL DO ESTADO PELO TRÁFICO DE PESSOAS À LUZ DAS DIRETRIZES DEFINIDAS PELO PROTOCOLO DE PALERMO por
}

KAREN REGINA SILVA DE OLIVEIRA

ORIENTADOR(A): Márcia Nina Bernardes 2012.2

PONTIFÍCIA UNIVERSIDADE CATÓLICA DO RIO DE JANEIRO

RUA MARQUÊS DE SÃO VICENTE, 225 - CEP 22453-900

RIO DE JANEIRO - BRASIL 


\title{
UMA ANÁLISE DA \\ RESPONSABILIDADE \\ INTERNACIONAL DO ESTADO \\ PELO TRÁFICO DE PESSOAS À \\ LUZ DAS DIRETRIZES \\ DEFINIDAS PELO PROTOCOLO \\ DE PALERMO
}

\author{
por \\ Karen Regina Silva de Oliveira
}

Monografia

apresentada

ao

Departamento de Direito da Pontificia Universidade Católica do Rio de Janeiro (PUC-Rio) para a obtenção do Título de Bacharel em Direito.

Orientador(a): Márcia Nina Bernardes

2012.2 


\section{AGRADECIMENTOS}

A Deus, pela graça da existência e pelo seu amor sem limites.

A Jesus, em quem eu encontro coragem a cada dia, sobretudo quando nada parece dar certo.

Aos meus pais, por todo o amor, zelo, e por terem me fornecido as condições para que eu me tornasse a pessoa que hoje sou.

A minha mãe Tania, pelo exemplo, carinho, e por não ter medido esforços no tornar a minha vida mais feliz.

Aos meus queridos irmãos, Paulo e Vivi, por todo incentivo, brigas, risadas e carinho de sempre.

A toda a minha família, em especial minha avó Bety e minha madrinha Ana Maria, por sempre torcerem pela minha felicidade.

Aos amigos que tive a sorte de encontrar durante a faculdade, em especial, Tiz, Paty, Rafa, Ana, André, Daniel, e Pryscila, por toda a descontração, brincadeiras, apoio, mas, sobretudo, pela certeza de uma amizade sincera.

As minhas amigas Priscila, Laís, Luíza, e Gisele, pela convivência alegre e por terem estado ao meu lado todos esses anos.

À Marina, por me lembrar de acreditar nos meus sonhos.

À Dra. Maria Izabel, por todo o ensinamento e aprendizado do lado prático do Direito, sempre com cuidado e paciência.

À professora e orientadora, Márcia Nina, por me incentivar a conseguir o melhor de mim, e também pela excelente e cuidadosa orientação.

Ao grupo Simulações e Realidade, e a todos do Núcleo de Direitos Humanos, em especial, Andrea e Juliana, pelas grandes experiências e por 
terem me permitido conhecer e aprofundar o estudo dos direitos humanos, tornando a faculdade um espaço mais prazeroso. 


\section{RESUMO:}

O presente trabalho tem por objetivo realizar uma análise da responsabilidade internacional do Estado pelo tráfico de pessoas à luz das diretrizes estatuídas pelo Protocolo de Palermo. Para tanto, inicialmente será apresentado o conceito de tráfico de pessoas e a evolução em seu tratamento normativo no âmbito do direito internacional. Em seguida, serão destacados os aspectos mais relevantes acerca do tema da responsabilidade internacional do Estado a fim de demonstrar possibilidade de imputar a um Estado o cometimento de violações desse gênero. E finalmente, a partir das diretrizes de prevenção e combate ao tráfico, proteção das vítimas, e cooperação internacional, definidas no Protocolo de Palermo, serão explicitadas as obrigações estatais no que diz respeito ao tratamento e enfrentamento deste fenômeno, no intuito de indicar um conteúdo mínimo a ser respeitado pelos Estados.

\section{PALAVRAS-CHAVE:}

Tráfico internacional de pessoas. Responsabilidade internacional do Estado. Conduta de agentes privados. Devida diligência. Protocolo de Palermo. Obrigações estatais. Proteção das vítimas. Prevenção e combate. Cooperação internacional. 


\section{SUMÁRIO}

Introdução

10

Capítulo 1 - Da evolução no tratamento normativo do tráfico de pessoas no direito internacional

Capítulo 2 - Da Responsabilidade Internacional do Estado pela prática de atos ilícitos

2.1. Da violação de uma obrigação internacionalmente estatuída

2.2. Da possibilidade de atribuição de responsabilidade internacional 25

2.3 Da responsabilidade internacional do Estado pela conduta de agentes privados

2.4 Do parâmetro da devida diligência

Capítulo 3 - O conteúdo das obrigações estatais no tráfico internacional de pessoas a partir das diretrizes definidas no Protocolo de Palermo

a) A situação de vulnerabilidade das vítimas de tráfico de pessoas 36

b) A demanda que fomenta o tráfico de pessoas

c) A criação ou manutenção de um ambiente que facilite a atuação dos traficantes e seus cúmplices com impunidade 
a) Da obrigação de criminalizar o tráfico de pessoas $\quad 50$

b) Da obrigação de investigar e processar as violações de direitos relacionadas ao tráfico

c) Da obrigação de impor sanções efetivas e proporcionais 55

3.2. Da diretriz de proteção das vítimas de tráfico de pessoas

a) Da obrigação de identificação das vitimas

b) Da obrigação de não criminalização e não detenção

59

c) $\mathrm{Da}$ desvinculação do oferecimento de proteção da obrigatoriedade de cooperação por parte das pessoas traficadas

d) Da proteção contra danos adicionais

64

e) Demais aspectos atinentes à proteção das vítimas de tráfico

66

3.3 Da diretriz de cooperação internacional 69

Conclusão 


\section{ABREVIAÇÕES}

\begin{tabular}{|c|c|}
\hline CORTE IDH & Corte Interamericana de direitos humanos \\
\hline CORTE EDH & Corte Europeia de direitos Humanos \\
\hline ONU & Organização das Nações Unidas \\
\hline CEDAW & Comitê para a Eliminação de todas as Formas de Discriminação contra a \\
& Mulher \\
\hline OEA & Organização dos Estados Americanos \\
\hline OC & Opinião Consultiva \\
\hline
\end{tabular}


"Our lives begin to end the day we become silent about things that matter" - Martin Luther King Jr. 


\section{Introdução}

O tráfico de pessoas é um fenômeno global e que não conhece limites. Nenhum país, seja como fonte, destinação, ou país de trânsito, está imune. ${ }^{1}$ Embora sejam a grande maioria, suas vítimas não são apenas mulheres e crianças, mas também homens, que são rotineiramente tratados como mercadoria, têm sua liberdade de ir e vir cerceada, e sofrem outras inúmeras séries de violações em seus direitos humanos.

De acordo com a Organização Internacional do Trabalho (ILO), em uma escala global, cerca de 2,4 milhões de pessoas são vítimas do tráfico de seres humanos, de modo que o tráfico se apresenta como uma das formas mais lucrativas de crime organizado, seguindo o tráfico de drogas e de armas. Estima-se que o tráfico de pessoas gere o lucro anual de $\$ 32$ bilhões de dólares ${ }^{2}$.

Ocorre que, se nos séculos passados, constituía-se essencialmente, para a obtenção de prisioneiros de guerra para a escravidão, vindo depois a assentar-se sob as bases do tráfico de escravos, e posteriormente, do tráfico de escravas brancas para a prostituição, contemporaneamente, um espectro muito maior de práticas se encontra diretamente atrelado a este fenômeno.

Trata-se de uma prática internacionalmente reconhecida como ilegal, que, hoje em dia, se perpetua através da servidão, da exploração para o trabalho escravo e outras práticas similares, para fins de extração de órgãos, através de atividades de exploração sexual, da qual a prostituição é apenas uma espécie ${ }^{3}$, etc.

\footnotetext{
${ }^{1}$ Organização das Nações Unidas. Notícia de 26 de março de 2007. Disponível em: <http://www.un.org/apps/news/story.asp?NewsID=22009>. Acesso em 29 maio 2012.

${ }^{2}$ Organização das Nações Unidas. Escritório das Nações Unidas sobre Drogas e Crime. Notícia de 03 de abril de 2012. Disponível em:

<http://www.unodc.org/unodc/en/frontpage/2012/April/un-general-assembly-president-calls-forre-doubled-efforts-to-end-human-trafficking.html?ref=fs1>. Acesso em 20 maio 2012.

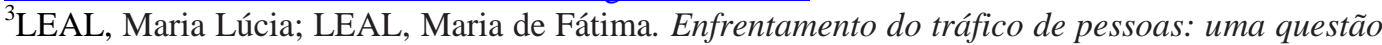
possível? $\quad$ p. $30 . \quad$ Disponível em: $\langle$ http://bvsms.saude.gov.br/bvs/publicacoes/politica_enfrentamento_trafico_pessoas.pdf $>$. Acesso em 11 setembro 2012.
} 
O Protocolo Adicional à Convenção das Nações Unidas contra o Crime Organizado Transnacional, relativo à Prevenção, Repressão e Punição do Tráfico de Pessoas, em especial Mulheres e Crianças, doravante Protocolo do Tráfico ou Protoloco de Palermo, relaciona as aludidas práticas ao trazer, em seu artigo $3^{\circ}$, a definição de tráfico de pessoas ${ }^{4}$. Porém, como o próprio Protocolo estabelece, a exploração pode se dar por outros meios, sendo aqueles apenas indicativos das formas mais comuns através das quais esse odioso crime se desenvolve e atinge sua finalidade.

Formas desta prática igualmente invisíveis e violatórias aos direitos humanos ocorrem, a exemplo do tráfico para casamento forçado, tráfico de crianças para adoção, tráfico para mendicância, etc. Todas atividades assentadas em alguma forma de exploração e sacrifício, e, perpetradas contra a vontade das vítimas, de modo que o tráfico internacional de pessoas é comumente identificado como uma forma moderna de escravidão ${ }^{5}$.

Embora tenham sido logrados muitos avanços frutos da mobilização da comunidade internacional, na prática, as medidas estatais adotadas ainda se mostram insuficientes, revelando, dentre outros aspectos, a falta de conhecimento sobre o tema e até mesmo questões mais sensíveis, como a falta de vontade política para combatê-lo.

Considerando que se trata de uma violação de direitos humanos que ocorre em escala mundial, a complexidade do cenário em que se desenvolve, e, também, que se apresenta como o crime que mais cresce em

\footnotetext{
${ }^{4}$ Art. $3^{\text {o: }}$ Para efeitos do presente Protocolo: [...] a) A expressão "tráfico de pessoas" significa o recrutamento, o transporte, a transferência, o alojamento ou o acolhimento de pessoas, recorrendo à ameaça ou uso da força ou a outras formas de coação, ao rapto, à fraude, ao engano, ao abuso de autoridade ou à situação de vulnerabilidade ou à entrega ou aceitação de pagamentos ou benefícios para obter o consentimento de uma pessoa que tenha autoridade sobre outra para fins de exploração. A exploração incluirá, no mínimo, a exploração da prostituição de outrem ou outras formas de exploração sexual, o trabalho ou serviços forçados, escravatura ou práticas similares à escravatura, a servidão ou a remoção de órgãos.

${ }^{5}$ GALLAGUER, Anne. The International Law of Human Trafficking. First paperback edition. New York: Cambridge University Press, 2012. p.189.
} 
todo o planeta ${ }^{6}$, o presente trabalho objetiva realizar uma análise da responsabilidade internacional do Estado pelo tráfico de pessoas à luz das diretrizes definidas no Protocolo de Palermo, que consistem nas obrigações de prevenção e combate ao tráfico, proteção das vítimas, e cooperação internacional com vistas a atingir esses objetivos.

Desse modo, em um primeiro capítulo, será apresentado o conceito de tráfico de pessoas e a evolução em seu tratamento no âmbito do direito internacional, até o Protocolo de Palermo, o principal instrumento internacional em vigor na matéria atualmente.

Em um segundo capítulo será abordado o tema da responsabilidade estatal a fim de verificar a possibilidade específica de imputar aos Estados a responsabilidade por violações desse tipo, tendo em vista que o tráfico é geralmente perpetrado por entes particulares, com ou sem a aquiescência de agentes estatais.

E, em um terceiro capítulo, adotando como ponto de partida as linhas de atuação definidas no Protocolo de Palermo, e como fontes, standards internacionalmente consolidados, será analisado o conteúdo das obrigações internacionalmente estatuídas em relação ao tráfico de pessoas, no que diz respeito ao tratamento e enfrentamento deste fenômeno,

Nesse sentido, o presente trabalho monográfico valer-se-á, para apontar um conjunto mínimo de obrigações a serem respeitadas no que diz respeito a esta matéria, tanto de fontes de direito internacional do sistema global, como também de fontes no âmbito dos sistemas regionais, notadamente do sistema europeu e interamericano de direitos humanos.

\footnotetext{
${ }^{6}$ Organização das Nações Unidas. Notícia de 11 de outubro de 2010. Disponível em: < http://www.unhcr.org/4cb315c96.html>. Acesso em 5 novembro 2012.
} 


\section{CAPÍTULO 1 - DA EVOLUÇÃO DO TRATAMENTO NORMATIVO DO TRÁFICO DE PESSOAS NO DIREITO INTERNACIONAL}

O tráfico de pessoas, em definição extraída do Protoloco de Palermo, consiste no:

[...] recrutamento, o transporte, a transferência, o alojamento ou o acolhimento de pessoas, recorrendo à ameaça ou uso da força ou a outras formas de coação, ao rapto, à fraude, ao engano, ao abuso de autoridade ou à situação de vulnerabilidade ou à entrega ou aceitação de pagamentos ou benefícios para obter o consentimento de uma pessoa que tenha autoridade sobre outra para fins de exploração. ${ }^{7}$

A exploração, também nos termos do referido Protocolo:

[...] incluirá, no mínimo, a exploração da prostituição de outrem ou outras formas de exploração sexual, o trabalho ou serviços forçados, escravatura ou práticas similares à escravatura, a servidão ou a remoção de órgãos.

A definição contida no Protocolo de Palermo reflete o tráfico tal como ele hoje se apresenta. Não obstante, esta prática não é um fenômeno do século XXI, sendo, por essa razão, também identificado como uma forma moderna de escravidão. Perpassando pelo tráfico para a obtenção de prisioneiros de guerra para a escravidão, e pelo tráfico de escravos africanos, o tráfico de pessoas, tal como hoje se apresenta, é tido como a continuação histórica do tráfico de escravas brancas (White Slave Trade), datado no final do século XIX e início do século XX. ${ }^{8}$

O tráfico de escravos africanos, embora iniciado pelos árabes no século $\mathrm{IX}^{9}$, teve sua repressão iniciada somente no século XIX, momento em que já apresentava uma feição comercial. ${ }^{10} \mathrm{O}$ primeiro instrumento

\footnotetext{
${ }^{7}$ Artigo 3, (a), do Protocolo de Palermo.

${ }^{8}$ ARY, Thalita Carneiro. O tráfico de pessoas em três dimensões: evolução, globalização e a rota Brasil-Europa.Brasília.2009. p. 23. Dissertação de Mestrado - Instituto de Relações Internacionais da Universidade de Brasília. Disponível em: <http://cnj.jus.br/dpj/cji/bitstream/26501/1402/1/Tese_O\%20tr\%C3\%A1fico\%20de\%20pessoas\% $20 \mathrm{em} \% 20 \mathrm{tr} \% \mathrm{C} 3 \%$ AAs\%20dimens\%C3\%B5es.pdf $>$.

${ }^{9}$ COMPARATO, Fábio Konder. A afirmação histórica dos direitos humanos. $6{ }^{\mathrm{a}}$ ed..São Paulo: Saraiva, 2008. p. 200.

${ }^{10}$ Ibid. p. 202.
} 
legal que enfrentou o tema, em âmbito internacional, foi o Tratado de Paris, firmado, em 1814, entre Inglaterra e França.

Posteriormente, em 1926, foi elaborada a Convenção de Genebra sobre a Escravatura. Esta Convenção, em que pese tenha reconhecido como obrigações estatais impedir e reprimir o tráfico, em outro espeque, previa que a abolição completa da escravidão, sob todas as suas formas, dar-se-ia, progressivamente, e assim que possível ${ }^{11}$, revelando a fragilidade dos compromissos firmados.

Em 1953, a referida Convenção é emendada através da elaboração de um Protocolo, a fim de adaptar suas disposições ao sistema das Nações Unidas e à Corte Internacional de Justiça, e, em 1956, cria-se a Convenção Suplementar sobre a Abolição da Escravatura, do Tráfico de Escravos, e das Instituições e Práticas Análogas à Escravatura, adotada em Genebra. ${ }^{12}$

Ao mesmo tempo em que se iniciavam as primeiras tentativas da comunidade internacional para normatizar o fenômeno do tráfico de escravos, já se desenvolvia, no final do século XIX e início do século XX, impulsionado pelos fluxos migratórios com a globalização do capitalismo, uma nova espécie de tráfico de pessoas, o tráfico de escravas brancas. ${ }^{13}$

Esta espécie de tráfico aparece como a principal raiz do tráfico contemporâneo. Embora esteja relacionado à prática da venda de mulheres para a prostituição, nesse período, o tráfico já era entendido como uma

\footnotetext{
${ }^{11}$ Ibid. p. 205.

${ }^{12}$ CASTILHO, Ela Wiecko V. Tráfico de pessoas: da Convenção de Genebra ao Protocolo de Palermo. p. 1. Disponível em: < http://pfdc.pgr.mpf.gov.br/atuacao-e-conteudos-deapoio/publicacoes/trafico-de-pessoas/artigo trafico_de pessoas.pdf>. Acesso em 03 junho 2012. ${ }^{13}$ ARY, Thalita Carneiro. O tráfico de pessoas em três dimensões: evolução, globalização e a rota Brasil-Europa.Brasília.2009. p. 24. Dissertação de Mestrado - Instituto de Relações Internacionais da Universidade de Brasília. Disponível em: <http://cnj.jus.br/dpj/cji/bitstream/26501/1402/1/Tese_O\%20tr\%C3\%A1fico\%20de\%20pessoas\% 20em\%20tr\%C3\%AAs\%20dimens\%C3\%B5es.pdf >. Acesso em 12 março 2012.
} 
forma de escravidão ${ }^{14}$, e desse modo, sua análise possui grande relevância para o debate do tráfico em seus contornos atuais.

Em 1904, a partir das discussões da Conferência de Paris (1902), foi criado, com a participação de treze países, o primeiro instrumento normativo internacional a respeito do tráfico de escravas brancas, o Acordo Internacional para a Supressão do Tráfico de Escravas Brancas ${ }^{15}$. As discussões foram focadas especificamente na questão da venda de escravas brancas do continente europeu, o que foi alvo de inúmeras críticas por não abranger mulheres de outras raças ${ }^{16}$.

Ao referido acordo segue-se a elaboração, em 1910, da Convenção Internacional para a Supressão do Tráfico de Escravas Brancas, também denominada de Convenção de Paris. Foi a partir deste documento que os instrumentos internacionais começaram a definir o tráfico e a exploração da prostituição como infrações penais a serem punidas com pena privativa de liberdade e em relação às quais poderia aplicar-se a extradição ${ }^{17}$.

Esta convenção possui como notas distintivas do acordo anterior o aumento da preocupação com as causas do fenômeno, e o reconhecimento da necessidade de implementação de medidas tanto administrativas quanto legislativas por parte dos Estados de modo a sancionar os agentes e estabelecer uma regulamentação desta prática. Contudo, assim como no Acordo de 1904, a ideia de tráfico de pessoas refletida nesta Convenção ainda se apresentava diretamente conectada à questão da prostituição ${ }^{18}$.

\footnotetext{
${ }^{14}$ AUSSERER, Caroline. Controle em nome da proteção: Análise dos discursos sobre o tráfico internacional de pessoas. Rio de Janeiro. 2007. Dissertação de Mestrado - Instituto de Relações Internacionais da Pontifícia Universidade Católica do Rio de Janeiro. p. 27.

${ }^{15}$ Ibid. p. 34.

${ }^{16} \mathrm{ARY}$, Thalita Carneiro. O tráfico de pessoas em três dimensões: evolução, globalização e a rota Brasil-Europa.Brasília.2009. p. 29. Dissertação de Mestrado - Instituto de Relações Internacionais da Universidade de Brasília. Disponível em: <http://cnj.jus.br/dpj/cji/bitstream/26501/1402/1/Tese_O\%20tr\%C3\%A1fico\%20de\%20pessoas\% 20em\%20tr\%C3\%AAs\%20dimens\%C3\%B5es.pdf >. Acesso em 12 março 2012.

${ }^{17}$ CASTILHO, Ela Wiecko V. Tráfico de pessoas: da Convenção de Genebra ao Protocolo de Palermo. p. 2. Disponível em: < http://pfdc.pgr.mpf.gov.br/atuacao-e-conteudos-deapoio/publicacoes/trafico-de-pessoas/artigo trafico_de_pessoas.pdf $>$. Acesso em 03 junho 2012.

${ }^{\frac{18}{18} \text { ARY, Thalita Carneiro. Op.cit., p. } 30 .}$
} 
Anos mais tarde, em 1921, é cunhada, no âmbito da Liga das Nações, a Convenção Internacional para a Supressão do Tráfico de Mulheres e Crianças. De acordo com esta Convenção, as vítimas do tráfico passam a ser qualquer mulher ou criança, desaparecendo, assim, a menção a questões raciais $^{19}$.

Outra importante inovação foi trazida pelo instrumento seguinte, a Convenção de Genebra de 1933, também chamada de Convenção para a Repressão do Tráfico de Mulheres Maiores. Se nos instrumentos anteriores a coação era exigida para fins da caracterização do tráfico, neste, o consentimento torna-se irrelevante ${ }^{20}$.

Após o nascimento das Nações Unidas, em 1947, a Convenção anterior é emendada através de um Protocolo, e dois anos mais tarde, em 1949, cria-se a Convenção das Nações Unidas para a Supressão do Tráfico de Pessoas e da Exploração da Prostituição de Outrem, também chamada de Convenção para a Repressão do Tráfico de Pessoas e do Lenocínio ${ }^{21}$.

Neste documento a referência às mulheres como vítimas dá lugar à expressão "pessoas", determinando que qualquer pessoa pode vir a ser vítima do tráfico. Por outro lado, a existência de uma relação inexorável entre tráfico e prostituição é enfatizada. A prostituição, tanto a exercida voluntariamente quanto a forçada, aparece ao lado do tráfico como uma prática igualmente condenável, pois violatória da dignidade humana e em desacordo com os padrões sociais ${ }^{22}$.

Além de não definir o termo tráfico de pessoas, esta Convenção não explicitou outras práticas fins, além da prostituição, para as quais o tráfico

\footnotetext{
${ }^{19}$ AUSSERER, Caroline. Controle em nome da proteção: Análise dos discursos sobre o tráfico internacional de pessoas. Rio de Janeiro. 2007. Dissertação de Mestrado - Instituto de Relações Internacionais da Pontifícia Universidade Católica do Rio de Janeiro. p. 36.

${ }^{20}$ Ibid. p. 36.

${ }^{21}$ CASTILHO, Ela Wiecko V. Tráfico de pessoas: da Convenção de Genebra ao Protocolo de Palermo. p. 2. Disponível em: < http://pfdc.pgr.mpf.gov.br/atuacao-e-conteudos-deapoio/publicacoes/trafico-de-pessoas/artigo trafico_de_pessoas.pdf>. Acesso em 03 junho 2012.

${ }^{22}$ AUSSERER, Caroline. Op. cit., p. 37.
} 
se perpetua. De igual modo, pouca atenção foi direcionada para a questão das causas do trafico ${ }^{23}$.

Em 1995, com a aprovação de uma Plataforma de Ação na Quarta Conferência Mundial sobre a Mulher, ocorrida em Beijing, é adotado, em contraposição ao modelo da Convenção de 1949, o conceito de prostituição forçada como uma forma de violência ${ }^{24}$, o que, de certo modo, e pelo menos em um plano formal, desvincula o conceito de tráfico de pessoas do conceito de prostituição, haja vista que descaracteriza a prostituição exercida livremente como uma pratica necessariamente violatória dos direitos humanos.

No ano de 1998, surgem duas importantes previsões a respeito do tráfico de pessoas. O Estatuto do Tribunal Penal Internacional, que passa a definir os crimes de escravidão sexual e de prostituição forçada, isto é, duas das inúmeras atividades fins do tráfico, como crimes contra a humanidade e de guerra. E a Convenção Interamericana sobre o Tráfico Internacional de Menores, que institui um tratamento específico para o caso de tráfico internacional de pessoas menores de dezoito anos ${ }^{25}$.

No ano de 2000, após a criação de um comitê intergovernamental pela Assembleia Geral da ONU, é cunhada a Convenção das Nações Unidas contra o Crime Organizado Transnacional. Esta Convenção é complementada por três protocolos integrados, sendo um deles o Protocolo para Prevenir, Reprimir, e Punir o Tráfico de Pessoas, especialmente Mulheres e Crianças (doravante Protocolo de Palermo ou Protocolo do

\footnotetext{
${ }^{23}$ ARY, Thalita Carneiro. O tráfico de pessoas em três dimensões: evolução, globalização e a rota Brasil-Europa.Brasília.2009. p. 33. Dissertação de Mestrado - Instituto de Relações Internacionais da Universidade de Brasília. Disponível em: $<$ http://cnj.jus.br/dpj/cji/bitstream/26501/1402/1/Tese_O\%20tr\%C3\%A1fico\%20de\%20pessoas\% 20em\%20tr\%C3\%AAs\%20dimens\%C3\%B5es.pdf >. Acesso em: 12 março 2012.

${ }^{24}$ CASTILHO, Ela Wiecko V. Tráfico de pessoas: da Convenção de Genebra ao Protocolo de Palermo. p. 4. Disponível em: < http://pfdc.pgr.mpf.gov.br/atuacao-e-conteudos-deapoio/publicacoes/trafico-de-pessoas/artigo trafico_de pessoas.pdf>. Acesso em 03 junho 2012. ${ }^{25}$ Ibid. p.4.
} 
Tráfico), cuja elaboração permite a inauguração de uma nova fase no tratamento do tráfico de pessoas ${ }^{26}$.

O Protocolo é, atualmente, o principal instrumento internacional em matéria de tráfico e em comparação com os instrumentos anteriores se apresenta como um importante avanço no enfrentamento do fenômeno.

A começar pelos sujeitos protegidos, que nos documentos anteriores eram, primeiramente, as mulheres brancas, e posteriormente, as mulheres e as crianças, o Protocolo estipula como vítimas do tráfico os seres humanos, não deixando de reconhecer, no entanto, a proteção especial que deve ser direcionada às mulheres e crianças ${ }^{27}$, que figuram como o maior percentual do total de pessoas traficadas.

Outra mudança diz respeito aos propósitos do tráfico. O Protocolo ${ }^{28}$ passa a prever a expressão "para fins de exploração"29, abarcando não apenas a prostituição, mas qualquer outra atividade assentada em alguma forma de sacrifício e exercida contra a vontade da pessoa explorada. Indica, assim, apenas exemplos das práticas mais comuns através das quais o tráfico atinge sua finalidade, a exemplo da servidão, do trabalho escravo, da exploração sexual, da extração de órgãos, etc.

Relativamente ao consentimento, este se torna irrelevante uma vez que a vítima tenha sido submetida "à ameaça ou uso da força ou a outras

\footnotetext{
${ }^{26}$ Ibid. p.5.

${ }^{27}$ Neste sentido o Protocolo de Palermo em seu art. $2^{\circ}$ : Os objetivos do presente Protocolo são os seguintes: a) Prevenir e combater o tráfico de pessoas, prestando uma atenção especial às mulheres e às crianças.

28 Art. $3^{\circ}$ : a) A expressão "tráfico de pessoas" significa o recrutamento, o transporte, a transferência, o alojamento ou o acolhimento de pessoas, recorrendo à ameaça ou uso da força ou a outras formas de coação, ao rapto, à fraude, ao engano, ao abuso de autoridade ou à situação de vulnerabilidade ou à entrega ou aceitação de pagamentos ou benefícios para obter o consentimento de uma pessoa que tenha autoridade sobre outra para fins de exploração. A exploração incluirá, no mínimo, a exploração da prostituição de outrem ou outras formas de exploração sexual, o trabalho ou serviços forçados, escravatura ou práticas similares à escravatura, a servidão ou a remoção de órgãos.

${ }^{29}$ CASTILHO, Ela Wiecko V. Tráfico de pessoas: da Convenção de Genebra ao Protocolo de Palermo. p. 5. Disponível em: < http://pfdc.pgr.mpf.gov.br/atuacao-e-conteudos-deapoio/publicacoes/trafico-de-pessoas/artigo trafico de pessoas.pdf $>$. Acesso em: 03 junho 2012.
} 
formas de coação, ao rapto, à fraude, ao engano" ${ }^{30}$, dentre outros meios listados.

Ademais, o Protocolo acolhe ainda uma preocupação maior com os sujeitos traficados estabelecendo disposições específicas para a assistência e tratamento das vítimas ${ }^{31}$. Suas previsões são orientadas de modo a não perpetuar as graves violações a que essas pessoas são submetidas, ou seja, não revitimizá-las, tendo em vista que é uma prática muito comum dos países tratar estas pessoas apenas como uma ferramenta para alcançar a punição dos traficantes $^{32}$.

Não se pode negar os avanços logrados tanto no reconhecimento da existência do tráfico como em seu enfrentamento. O Protocolo de Palermo entrou em vigor em 25 de dezembro de 2003, e desde então, vem sendo constatados progressos em relação ao número de ratificações que resultam em alterações na legislação interna dos países $^{33}$. Muitos Estados já contam com disposições legislativas e procedimentos específicos para assegurar o enfrentamento e uma proteção mais efetiva contra o tráfico ${ }^{34}$.

Não obstante, também merece destaque $o$ fato de que a implementação das disposições do Protocolo ainda segue sendo um problema, no sentido de que para explorar a capacidade total dos Estados de adotar e colocar em prática medidas eficazes no combate ao tráfico, muitos esforços ainda devem ser feitos ${ }^{35}$.

\footnotetext{
${ }^{30}$ Art. $3^{\circ}$, (a), do Protocolo de Palermo.

${ }^{31}$ A título de exemplo, os artigos 6, 7, e 8 do Protocolo de Palermo são inteiramente destinados à proteção das vítimas de tráfico. Ademais, o artigo 14.2 estabelece que "as medidas constantes do presente Protocolo serão interpretadas e aplicadas de forma a que as pessoas que foram vítimas de tráfico não sejam discriminadas".

${ }^{32}$ GALLAGUER, Anne. The International Law of Human Trafficking. First paperback edition. New York: Cambridge University Press, 2012. p. 283.

33 ORGANIZAÇÃO DAS NAÇÕES UNIDAS. Escritório das Nações Unidas sobre Drogas e Crime. International Framework for Action: to Implement the Trafficking in Persons Protocol. Disponível em: <http://www.unodc.org/documents/humantrafficking/Framework_for_Action_TIP.pdf $>$. Acesso em 11 setembro 2012.

${ }^{34}$ GALLAGUER, Anne. Op. cit., p. 3.

35 ORGANIZAÇÃO DAS NAÇÕES UNIDAS. Escritório das Nações Unidas sobre Drogas e Crime. International Framework for Action: to Implement the Trafficking in Persons Protocol.
} 
A contribuir para esta situação, os Estados consistentemente negam ${ }^{36}$ a responsabilidade por este fenômeno ${ }^{37}$, e entre os argumentos apresentados para tal negativa, comumente se encontram alegações nas quais é reforçada a ausência de responsabilidade estatal por ser o ato de traficar cometido por grupos criminosos, e não propriamente pelo Estado. Em outros casos, os Estados afirmam ter realizado tudo o que era possível de modo a evitar os danos advindos desta prática ${ }^{38}$.

Assim, considerando o panorama atual, e o fato de que o cumprimento, por parte de cada Estado, de um conteúdo mínimo de obrigações no que diz respeito ao tráfico de pessoas, todas elas com foco nas vítimas, se faz imprescindível para que essa prática seja abolida ou ao menos minorada, é que se passará a analisar mais detidamente as obrigações estatais no tema. Adotar-se-á como base para tanto, as três linhas de atuação definidas pelo Protocolo do Tráfico, que consistem na prevenção e combate ao tráfico, proteção das vítimas, e cooperação internacional com vistas a atingir esses objetivos.

Antes, porém, é imperioso que sejam feitas algumas considerações sobre os requisitos necessários para que se possa imputar a um Estado a responsabilidade pela prática de um ilícito internacional, ou seja, a respeito do instituto da responsabilidade internacional dos Estados.

\footnotetext{
Disponível em: $\quad$ emttp://www.unodc.org/documents/humantrafficking/Framework for_Action_TIP.pdf >. Acesso em 11 setembro 2012.

${ }^{36}$ Questão levantada durante os encontros ocorridos sob os auspícios das Nações Unidas, nos anos de 1998 e 1999, em Vienna, Áustria.

${ }^{37}$ GALLAGUER, Anne. The International Law of Human Trafficking. First paperback edition. New York: Cambridge University Press, 2012. p 219.

${ }^{38}$ Ibid. p. 219.
} 


\section{CAPÍTULO 2 - DA RESPONSABILIDADE INTERNACIONAL DO ESTADO PELA PRÁTICA DE ATOS ILÍCITOS}

É uma diretriz básica de direito internacional que o cometimento de um ato atentatório do ponto de vista das obrigações internacionalmente estatuídas gera a responsabilidade dos Estados, e enseja, concomitantemente, a obrigação de reparar os danos decorrentes de tal ato. Trata-se do instituto da responsabilidade internacional, que representa, principalmente, a resposta que o Direito Internacional apresenta aos Estados que infringem suas regras ${ }^{39}$.

Do mesmo modo que os atos ilícitos que sejam praticados no âmbito interno dos Estados estão sujeitos a uma sanção e reparação nos termos de seus ordenamentos jurídicos, a prática, por parte de um Estado, de ilícitos internacionais, assim definidos como os atos que violam as normas de Direito Internacional Público, também deflagram a necessidade de responsabilização ${ }^{40}$.

Ainda que o ato atentatório não contravenha as normas internas do Estado, se infringe uma obrigação internacional, merece reparação. Mesmo que, de acordo com a lei interna, o Estado tenha sido realmente obrigado a agir dessa forma. É o que esclarecem os comentários ao artigo $3^{\circ}$ da Minuta de Artigos sobre Responsabilidade dos Estados por Atos Internacionalmente Ilícitos ${ }^{41}$ (ILC's Draft on State Responsability), doravante ILC's Draft, documento que procura definir as regras básicas de direito internacional sobre a responsabilidade dos Estados pela prática de atos internacionalmente ilícitos.

\footnotetext{
${ }^{39}$ MAZZUOLI, Valerio de Oliveira. Curso de Direito Internacional Público. $3^{\mathrm{a}}$ ed.. São Paulo: Editora Revista dos Tribunais, 2008. p. 500.

${ }^{40}$ Ibid. p. 502.

${ }^{41}$ ORGANIZAÇÃO DAS NAÇÕES UNIDAS. Draft articles on Responsibility of States for Internationally Wrongful Acts, with commentaries. Disponível em: 〈http://untreaty.un.org/ilc/texts/instruments/english/commentaries/9_6_2001.pdf> Acesso em: 19 julho 2012.
} 
Embora o conceito do referido instituto tenha surgido no bojo das relações entre Estados, a fim de responsabilizar determinado Estado pela prática de um ato ilícito cometido contra outro, ou outros Estados, note-se que pode ser igualmente aplicado nas relações entre o Estado e as pessoas sujeitas à sua jurisdição. É o caso das violações estatais aos direitos humanos ${ }^{42}$, no que se enquadra o tráfico internacional de pessoas.

Destaque-se ainda que as doutrinas modernas a respeito deste instituto não identificam o dano como elemento essencial para que seja deflagrada a responsabilidade internacional de um Estado, bastando, para tanto, a violação de uma obrigação existente. No mesmo sentido, a existência de culpa, que, mesmo em caso da responsabilização estatal por atos privados, não se faz necessária, a menos que alguma obrigação legal, especificamente, a exija ${ }^{43}$.

Existem dois elementos necessários para que seja possível imputar a um Estado a responsabilidade internacional pela prática de um ato ilícito. Primeiramente, deve ser verificada se a ação (ou omissão) pode ser atribuída ao Estado de acordo com as normas de Direito Internacional, e em segundo lugar, se aquele ato realmente consiste em uma violação das obrigações internacionalmente estatuídas vigentes ${ }^{44}$. A violação de uma obrigação estatal não pode deflagrar a responsabilização de um Estado sem que possa ser a ele imputada.

\subsection{Da violação de uma obrigação internacionalmente estatuída}

No que diz respeito ao requisito da violação de uma obrigação internacional, de acordo com o artigo 12 da ILC's Draft, existe uma violação das obrigações internacionalmente estatuídas vigentes por um Estado quando:

\footnotetext{
${ }^{42}$ MAZZUOLI, Valerio de Oliveira. Curso de Direito Internacional Público.3 ${ }^{\mathrm{a}}$ ed.. São Paulo: Editora Revista dos Tribunais, 2008. p. 502.

${ }^{43}$ GALLAGUER, Anne. The International Law of Human Trafficking. First paperback edition. New York: Cambridge University Press, 2012.p. 234.

${ }^{44}$ Ibid. p. 223.
} 
[...] an act of that State is not in conformity with what is required of it by that obligation, regardless of its origin or character. ${ }^{45}$

A única exceção a esta regra geral encontra-se na existência de circunstâncias especiais que, enquanto existirem, obstam a caracterização da conduta como um ilícito internacional, ainda que satisfeitos os dois requisitos anteriormente mencionados. A obrigação estatal continua a existir, fornecendo estas circunstâncias especiais circunstâncias apenas uma justificativa temporária para o seu descumprimento ${ }^{46}$.

Um exemplo dessa espécie de circunstância é estipulada na disposição do artigo $4^{\mathrm{o} 47}$ do Pacto Internacional de Direitos Civis e Políticos, que estabelece que em situações de perigo para a nação certos direitos consagrados neste instrumento poderão ser suspensos temporariamente pelos Estados Partes.

Fora da situação acima delineada, no entanto, para que se determine se a ação praticada consiste em uma violação das obrigações internacionalmente estatuídas, é exigida a verificação de quais são os termos precisos da obrigação, sua interpretação, seu modo de aplicação, bem como os fatos do caso $^{48}$, o que só pode ser realizado a partir de uma análise casuística.

As obrigações anteriormente referidas são as se encontram estatuídas nas fontes de direito internacional, a exemplo dos tratados, convenções, protocolos, e também regras costumeiras. Tais fontes estabelecem regras primárias, que exigem aos Estados a garantia de direitos a todos os que se

\footnotetext{
${ }^{45}$ ORGANIZAÇÃO DAS NAÇÕES UNIDAS. Draft articles on Responsibility of States for Internationally Wrongful Acts, with commentaries. Disponível em:

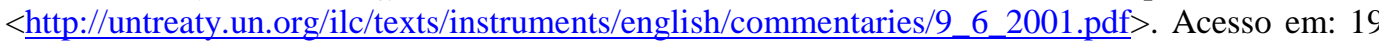
julho 2012.

${ }^{46}$ GALLAGUER, Anne. The International Law of Human Trafficking. First paperback edition. New York: Cambridge University Press, 2012.p. 230.

${ }^{47}$ Art. $4^{\circ}$ : 1. Em situações excepcionais de perigo para a nação, declaradas oficialmente, os Estados-Signatários do presente Pacto poderão adoptar disposições, nos limites estritamente exigidos pela situação, que suspendam as obrigações contraídas em virtude deste Pacto, sempre que tais disposições não sejam incompatíveis com as restantes obrigações que lhes impôe o direito internacional e não contenham nenhuma discriminação fundamentada. (...)

${ }^{48}$ GALLAGUER, Anne. The International Law of Human Trafficking. First paperback edition. New York: Cambridge University Press, 2012. p. 231.
} 
encontrem dentro de seu próprio território, ou estejam, de alguma forma, submetidos à sua jurisdição. É a partir delas que, em um primeiro momento, é formada uma relação jurídica entre Estados, ou entre Estado e indivíduo. Assim, ocorrendo o descumprimento de uma regra primária por um Estado, e podendo tal descumprimento ser a ele atribuído, é que surgem as regras secundárias, oriundas da imposição de responsabilidade internacional ao Estado, e que regulam as consequências decorrentes do descumprimento das regras primárias ${ }^{49}$.

No tocante à aplicação das regras primárias, importa ressaltar ainda o princípio geral segundo o qual um ato estatal não constitui uma violação a uma obrigação internacional a menos que ao tempo do descumprimento de tal obrigação o Estado já se encontre vinculado a ela ${ }^{50}$. Tal premissa possui implicações diretas no tocante ao tráfico internacional de pessoas, haja vista que, como já foi demonstrado anteriormente, a obrigação de criminalizar esta prática, sujeitando os Estados a obrigações no que toca esta matéria, é relativamente recente ${ }^{51}$.

Por outro lado, se o tráfico for identificado como uma forma moderna de escravidão, noção esta que se encontra bem difundida, outra consequência surge, qual seja, a de que os Estados encontram-se vinculados a esta obrigação desde o princípio de sua existência enquanto regra costumeira de direito internacional ${ }^{52}$. Isto porque, como uma regra costumeira de direito internacional, a proibição da escravidão é reconhecida como uma obrigação universal (erga omnes) e que não pode ser derrogada (jus cogens) ${ }^{53}$.

\footnotetext{
${ }^{49}$ ORGANIZAÇÃO DAS NAÇÕES UNIDAS. Draft articles on Responsibility of States for Internationally Wrongful Acts, with commentaries. Disponível em: <http://untreaty.un.org/ilc/texts/instruments/english/commentaries/9_6_2001.pdf >. Acesso em: 19 julho 2012.

${ }^{50}$ Comentários ao artigo 13 da $I L C$ 's Draft.

${ }^{51}$ GALLAGUER, Anne. The International Law of Human Trafficking. First paperback edition. New York: Cambridge University Press, 2012. p. 232.

${ }_{52}^{5}$ Ibid. p. 233.

${ }^{53}$ Ibid. p. 178.
} 


\subsection{Da possibilidade de atribuição de responsabilidade internacional}

Uma vez satisfeito o requisito da violação de uma obrigação, é preciso verificar se a ação (ou omissão) pode ser atribuída ao Estado de acordo com as normas de Direito Internacional.

No que diz respeito ao requisito da atribuição, a princípio, o Direito Internacional apenas reconhece como imputável ao Estado as condutas perpetradas por seus agentes e por órgãos governamentais, ou outros indivíduos que tenham atuado sob direção, instigação, ou controle desses órgãos ${ }^{54}$. É a chamada responsabilidade direta:

É a responsabilidade do Estado pela ação de seus órgãos de qualquer natureza ou nível hierárquico: não está excluída a possibilidade de imputar-se ao Estado o ilícito resultante do exercício de competências legislativas ou judiciárias ${ }^{55}$.

Tendo em vista que agentes estatais encontram-se imbuídos de poder público, não interessa a sua hierarquia, se o Estado repudiou o ato, se o ato cometido violou flagrantemente a competência conferida ao agente ou órgão, e nem mesmo se de acordo com as disposições da legislação interna ou com as instruções que possam ter sido dadas aos seus órgãos ou agentes, as ações ou omissões não deveriam ter ocorrido ${ }^{56}$. Mesmo nestes casos, a responsabilidade poderá ser imputada ao Estado ${ }^{57}$.

Assim sendo, à primeira vista, não parecem existir grandes obstáculos em se concluir pela atribuição de responsabilidade internacional originada na conduta de agentes e órgãos governamentais. Contudo, a verificação da possibilidade de atribuição de responsabilidade nestas situações pode se tornar complexa, em razão da dificuldade de se

\footnotetext{
${ }^{54}$ Ibid. p. 223.

${ }^{55}$ REZEK, José Francisco. Direito Internacional Público: Curso Elementar. $11^{a}$ ed.. São Paulo: Saraiva, 2008. p.271.

${ }_{57}^{56}$ Nesse sentido, a $I L C$ 's Draft em seus artigos $4^{\circ}$, e $7^{\circ}$, parágrafo $2^{\circ}$.

${ }^{57}$ GALLAGUER, Anne. The International Law of Human Trafficking. First paperback edition. New York: Cambridge University Press, 2012 .p. 224.
} 
determinar quando um indivíduo, agente estatal, está agindo em nome do Estado ou com base em interesses privados ${ }^{58}$.

Embora, em ambos os casos, considerando a função que desempenha, esteja agindo de forma abusiva e não autorizada, a situação na qual um individuo atua com aparente capacidade oficial difere em muito de quando atua de acordo com interesses puramente privados ${ }^{59}$.

Apenas no caso em que o agente esteja atuando com aparente capacidade oficial é que a ação poderá ser diretamente atribuída ao Estado. A responsabilidade deve ser excluída em situações nas quais o ato praticado não teve conexão com a função oficial, ou seja, em casos nos quais a autoridade dos agentes estatais não era aparente ${ }^{60}$.

Uma das formas de se verificar essa aparente autoridade é investigando se a posição oficial do indivíduo atuou como possibilitadora daquela conduta, ou seja, se a prática do ato só foi possível em razão das condições que sua função pública lhe forneceu ${ }^{61}$.

A título de exemplo, este é o caso de oficiais das fronteiras que, muitas vezes, são condescendentes com o tráfico em troca de alguma vantagem. Ainda que tal conduta seja contrária à lei interna e esteja, notoriamente, excedendo o poder a eles conferido, como o ato praticado vincula-se a sua função oficial no sentido de que foi esta que tornou possível a sua consecução, o Estado pode ser responsabilizado ${ }^{62}$.

No ponto, é relevante destacar que a defesa dos Estados contra acusações de envolvimento do setor público no tráfico é frequentemente baseada nas aludidas premissas ${ }^{63}$, ou seja, no fato de que tal conduta foi cometida em violação das regras vigentes internamente. Todavia, como

\footnotetext{
${ }^{58}$ Ibid. p. 225.

${ }^{59}$ Comentários ao artigo $4^{\circ}$ da ILC's Draft.

${ }^{60}$ Comentários ao artigo $4{ }^{\circ}$ da ILC's Draft.

${ }^{61}$ GALLAGUER, Anne. The International Law of Human Trafficking. First paperback edition. New York: Cambridge University Press, 2012. p. 227.

${ }^{62}$ Ibid. p. 226.

${ }^{63}$ Ibid. p. 226.
} 
supramencionado, tal alegação se revela insuficiente de acordo com os parâmetros internacionais.

A Corte Interamericana de Direitos Humanos, já em sua primeira decisão proferida no âmbito de sua jurisdição contenciosa, estabeleceu que os Estado devem ser responsabilizado por atos daqueles que se utilizam do poder público para violar os direitos humanos através de atos ilegais ou que ultrapassam a sua competência ${ }^{64}$. Neste sentido, a Corte asseverou que:

Esa conclusión es independiente de que el órgano o funcionario haya actuado en contravención de disposiciones del derecho interno o desbordado los límites de su propia competencia, puesto que es un principio de Derecho internacional que el Estado responde por los actos de sus agentes realizados al amparo de su carácter oficial y por las omisiones de los mismos aun si actúan fuera de los límites de su competencia o en violación del derecho interno. ${ }^{65}$

Ademais, é preciso frisar que ainda que não seja possível imputar ao Estado o ato de um agente seu que esteja se pautando unicamente em interesse privados, em uma situação na qual o ato praticado não teve conexão com a função oficial, se o Estado tinha como ter ciência das violações perpetradas, ele pode ser responsabilizado ${ }^{66}$. Isto se faz possível porque se o Estado tinha, ou ao menos deveria ter, conhecimento das ações ou omissões, ele deveria ter adotado alguma medida com o intuito de prevenir ou reprimir tais violações.

A ILC's Draft, nos comentários ao seu artigo $7^{\circ}$, propõe, nesse contexto, uma distinção baseada na frequência e organização com as quais o ato ocorre. Se a conduta não era uma prática isolada, mas sim recorrente, e fazia parte de um padrão de atuações de modo que o Estado deveria ter ciência de sua ocorrência, ele pode ser responsabilizado ${ }^{67}$. Nestas

\footnotetext{
${ }^{64}$ CORTE IDH. Caso Velásquez Rodríguez vs. Honduras. Sentença de 29 de julho de 1988. par 171.

${ }^{65}$ CORTE IDH. Caso Velásquez Rodríguez vs. Honduras. Sentença de 29 de julho de 1988. par 170.

${ }^{66}$ GALLAGUER, Anne. The International Law of Human Trafficking. First paperback edition. New York: Cambridge University Press, 2012. p. 227.

${ }^{67}$ ORGANIZAÇÃO DAS NAÇÕES UNIDAS. Draft articles on Responsibility of States for Internationally Wrongful Acts, with commentaries. Disponível em: 〈http://untreaty.un.org/ilc/texts/instruments/english/commentaries/9_6_2001.pdf〉. Acesso em: 19 julho 2012.
} 
circunstâncias, diferenciar uma conduta entre oficial ou privada não apresenta relevância, pois houve tolerância por parte do Estado, e como será adiante explicitado, o critério da ciência também se aplica na avaliação da responsabilidade internacional do Estado por ato de particular.

Outrossim, destaque-se que o exercício de funções públicas por indivíduos e entidades privadas, no âmbito da "privatização", como sugere a ILC's Draft em seu artigo5 ${ }^{\circ 68}$, não atua de modo a afastar a responsabilidade internacional do Estado, tendo em vista a própria natureza dos atos desempenhados, que continuam sendo serviços públicos de titularidade estatal. Esse é o caso, por exemplo, de empresas privadas de segurança contratadas pelo poder público para exercer o controle de fronteiras ${ }^{69}$.

Fora do sistema de privatização, no que diz respeito à conduta praticada por indivíduos privados que são recrutados pelo Estado para auxiliar, por exemplo, na aplicação da lei ou no desempenho de atividades militares, também pode ser atribuída responsabilidade ao Estado, haja vista que estes indivíduos, ao agirem sob as instruções, sob a direção, ou sob o controle estatal, embora não integrem formalmente a estrutura estatal, encontram-se vinculados a ela ${ }^{70}$.

Não é demais lembrar, contudo, que a aferição de tal vinculação é feita caso a caso, e que exige mais do que uma mera ligação. É preciso que o Estado esteja exercendo um controle efetivo sobre tais pessoas, isto é, uma demonstração de que tais pessoas agiam em nome do Estado ${ }^{71}$. Nos termos do artigo 8 da ILC's Draft:

\footnotetext{
${ }^{68}$ Art. $5^{\circ}:$ The conduct of a person or entity which is not an organ of the State under article 4 but which is empowered by the law of that State to exercise elements of the governmental authority shall be considered an act of the State under international law, provided the person or entity is acting in that capacity in the particular instance.

${ }^{69}$ GALLAGUER, Anne. The International Law of Human Trafficking. First paperback edition. New York: Cambridge University Press, 2012. p. 227.

${ }^{70}$ Ibid. p. 228.

${ }^{71}$ Ibid. p. 228.
} 
The conduct of a person or group of persons shall be considered an act of a State under international law if the person or group of persons is in fact acting on the instructions of, or under the direction or control of, that State in carrying out the conduct.

Em suma, deve existir uma circunstância especial que ligue a conduta destas pessoas ou entidades ao Estado, o que pode se manifestar sob a forma de autorização, controle, aprovação, apoio, ou mesmo consciência, por parte deste ${ }^{72}$.

\subsection{Da responsabilidade internacional do Estado pela conduta de agentes privados}

No tocante aos atos praticados por indivíduos ou entidades privadas, é um princípio geral de direito internacional que estes não são atribuíveis ao Estado $^{73}$.

Embora as regras mencionadas anteriormente indiquem um caminho, elas não abarcam todas as situações pelas quais um Estado pode ser responsabilizado internacionalmente a partir da conduta de pessoas e entidades que não integram a estrutura estatal. Tal premissa é especialmente verdadeira nos casos de tráfico internacional de pessoas considerando que, na maioria dos casos, ou não se faz presente o envolvimento direto do Estado, ou ele não é totalmente comprovado ${ }^{74}$. É preciso, desse modo, indicar outras regras atinentes à responsabilização estatal a partir de condutas privadas que possam responder a estas situações.

É cada vez mais aceito, especialmente na área de direitos humanos, o fato de que um Estado pode ser responsabilizado não apenas se diretamente desrespeita algum direito ou liberdade, mas também se falha em proteger adequadamente da ação de outros indivíduos aqueles que se encontram sob sua jurisdição ${ }^{75}$.

\footnotetext{
${ }^{72}$ Ibid. p. 230.

${ }^{73}$ Artigo $8^{\circ}$ da ILC'sDraft.

${ }^{74}$ GALLAGUER, Anne. The International Law of Human Trafficking. First paperback edition. New York: Cambridge University Press, 2012. p. 235.

${ }^{75}$ Ibid. p. 237.
} 
Trata-se da responsabilidade indireta ou subsidiária, que se desenvolve, dentre outras hipóteses, quando o ilícito for cometido por simples particulares, indivíduos que não representam formalmente o Estado. ${ }^{76}$ Destarte, apesar de o Estado não ser o deflagrador das violações, pode ser responsabilizado pelos danos e outras consequências delas advindas. Esta ideia encontra-se explicitada na ILC's Draft, que assim dispõe:

A State may be responsible for the effects of the conduct of private parties, if it failed to take necessary measures to prevent those effects. ${ }^{77}$

Os atos de particulares, desse modo, não dão causa à responsabilidade internacional do Estado, mas podem desencadeá-la, uma vez que este falte com seus deveres de prevenção e repressão ${ }^{78}$.

Ocorre que, atualmente, a falha dos Estados em assegurar inúmeros direitos humanos às pessoas que se encontram sob sua jurisdição é algo que já vem ensejando a responsabilidade destes por atos de particulares de maneira direta, isto é, em decorrência da violação de regras primárias. Tal fato se deve à enorme quantidade de normas de Direito Internacional de Direitos Humanos que acabaram por elevar ao status de primárias obrigações como proteger, respeitar, prevenir, e promover tais direitos ${ }^{79}$.

Ou seja, na falta de regras primárias como o artigo $9^{\mathbf{8} 80}$ do Protocolo de Palermo, por exemplo, um Estado só poderia ser responsabilizado por não prevenir o tráfico de pessoas perpetrado por particulares a partir de regras secundárias, que o obrigam a agir com cuidado para prevenir e punir

\footnotetext{
${ }^{76}$ MAZZUOLI, Valerio de Oliveira. Curso de Direito Internacional Público. $3^{\mathrm{a}}$ ed.. São Paulo: Editora Revista dos Tribunais, 2008. p. 509.

${ }^{77}$ Organização das Nações Unidas. Draft articles on Responsibility of States for Internationally Wrongful Acts, with commentaries. Disponível em:

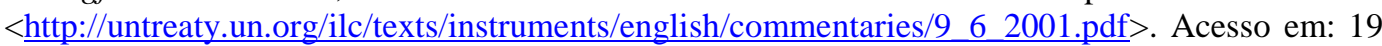
julho 2012.

${ }^{78}$ REZEK, José Francisco. Direito Internacional Público: Curso Elementar. $11^{a}$ ed.. São Paulo: Saraiva, 2008. p. 272.

${ }^{79}$ GALLAGUER, Anne. The International Law of Human Trafficking. First paperback edition. New York: Cambridge University Press, 2012. p. 238.

${ }^{80}$ Art. $9^{\circ}: 1$. Os Estados Partes estabelecerão políticas abrangentes, programas e outras medidas para: a) Prevenir e combater o tráfico de pessoas.
} 
os particulares que assim atuem. Mas, com disposições como esta, a responsabilidade internacional já pode ser diretamente imputada a este Estado.

Esse parâmetro também se reflete nas decisões judiciais das cortes regionais de direitos humanos. No caso Rantsev v. Chipre e Rússia (Rantsev v. Cyprus and Russia), por exemplo, importante precedente da Corte Europeia de Direitos Humano a respeito do tráfico de pessoas, ambos os Estados de Chipre e Rússia foram condenados, dentre outros aspectos, por terem falhado no empreendimento de uma investigação efetiva ${ }^{81}$.

Rantsev era uma cidadã russa que se mudou para o Chipre em um contexto de possível tráfico de pessoas e começara a trabalhar como artista em um cabaré. Após uma frustrada tentativa de fuga, ela acabou morrendo ao cair da varanda do apartamento de seu empregador, e embora as circunstâncias de sua morte tenham sido misteriosas, não foi empreendida pelo Estado qualquer investigação no intuito de esclarecer tais fatos, o que culminou com a responsabilização tanto do país de destino quanto do país de origem de Rantsev, nos termos dos artigos $2^{\circ}$ e $4^{\circ}$, e com a condenação do Chipre pela violação do artigo $5^{\circ}$, todos da Convenção Europeia de Direitos Humanos ${ }^{82}$.

\subsection{Do parâmetro da devida diligência}

Ainda no que diz respeito à responsabilidade internacional do Estado pela conduta de agentes não estatais, para avaliar tal responsabilidade, emprega-se o conceito da devida diligência. A devida diligência opera de modo a impor um padrão de atuação através do qual um Estado obriga-se a prevenir, investigar, e punir, de modo eficaz, a violação de direitos perpetrada por agentes privados.

\footnotetext{
${ }^{81}$ GALLAGUER, Anne. The International Law of Human Trafficking. First paperback edition. New York: Cambridge University Press, 2012. p. 241.

${ }^{82}$ CORTE EDH. Caso Rantsev v. Cyprus and Russia. Sentença de 7 de janeiro de 2010.
} 
Ainda que o Estado não seja responsável pelo dano imediato, a falha na prevenção ou na repressão de violações ao direito internacional implicará em sua responsabilidade internacional, tendo em vista que este falhou quando poderia ter agido de modo a impedir a violação ou punir os responsáveis ${ }^{83}$.

No já citado caso Velásquez Rodriguez vs. Honduras, a Corte Interamericana estabeleceu que no intuito de respeitar a devida diligência, os Estados devem:

[...] organizar todo el aparato gubernamental y, en general, todas las estructuras a través de las cuales se manifiesta el ejercicio del poder público, de manera tal que sean capaces de asegurar jurídicamente el libre y pleno ejercicio de los derechos humanos. Como consecuencia de esta obligación los Estados deben prevenir, investigar y sancionar toda violación de los derechos reconocidos por la Convención y procurar, además, el restablecimiento, si es posible, del derecho conculcado y, en su caso, la reparación de los daños producidos por la violación de los derechos humanos ${ }^{84}$.

De acordo com a Relatoria Especial das Nações Unidas sobre violência contra a mulher ${ }^{85}$, do padrão da devida diligência também decorre a obrigação de compensação pelos danos causados:

Due diligence requires more than the mere enactment of formal legal prohibitions. The States' measures must effectively prevent such actions. Failing effective prevention, a prompt and thorough investigation, resulting in prosecution of the culpable parties and compensation for the victim, must be undertaken. [...] In order to comply with the due diligence standard, the State must act in good faith.

Ressalte-se, no entanto, que a devida diligência só possibilita a responsabilização estatal por danos puramente privados caso existam normas primárias de conteúdo obrigacional impondo ao Estado a

\footnotetext{
${ }^{83}$ GALLAGUER, Anne. The International Law of Human Trafficking. First paperback edition. New York: Cambridge University Press, 2012. p. 242.

${ }^{84}$ CORTE IDH. Caso Velásquez Rodríguez vs. Honduras. Sentença de 29 de julho de 1988. par 166.

${ }^{85}$ ORGANIZAÇÃO DAS NAÇÕES UNIDAS. Economic and Social Council. Report of the Special Rapporteur on violence against women, its causes and consequences, Ms. Radhika Coomaraswamy, on trafficking in women, women's migration and violence against women, submitted in accordance with Commission on Human Rights resolution 1997/44E/CN.4/2000/68 29 February 2000. Disponível em: http://www.unhchr.ch/Huridocda/Huridoca.nsf/0/e29d45a105cd8143802568be0051fcfb/\$FILE/G0 011334.pdf >. Acesso em 12 outubro 2012.
} 
prevenção, investigação e punição dos abusos perpetrados ${ }^{86}$. Uma vez que existam normas nesse sentido, o que se verifica, como se passará a demonstrar, no caso de tráfico de seres humanos, a medida para verificar se tais obrigações estão sendo efetivamente cumpridas será a devida diligencia.

Neste sentido, para confirmar o fato de que, nos últimos anos, o parâmetro da devida diligência tem sido aplicado a um número cada vez maior de violações aos direitos humanos, inclusive no que diz respeito ao tráfico de pessoas ${ }^{87}$, cabe destacar o pronunciamento do Conselho de Direitos Humanos da ONU que, em uma de suas resoluções, assim asseverou:

[...] All States have an obligation to exercise due diligence to prevent trafficking in persons, to investigate and punish perpetrators, to rescue victims and to provide for their protection, and that not doing so violates and impairs or nullifies the enjoyment of the human rights and fundamental freedoms of victims $[\ldots]^{88}$.

\footnotetext{
${ }^{86}$ GALLAGUER, Anne. The International Law of Human Trafficking. First paperback edition. New York: Cambridge University Press, 2012. p. 244.

${ }^{87}$ ORGANIZAÇÃO DAS NAÇÕES UNIDAS. Economic and Social Council. Integration of the human rights of women and the gender perspective: violence against women .The due diligence standard as a tool for the elimination of violence aginst women. Disponivel em: $\langle$ http://www.coe.int/t/dg2/equality/domesticviolencecampaign/Source/PDF_UN_Sp_Rapp_report due diligence standard.pdf $>$. Acesso em 27 outubro 2012.

${ }^{88}$ ORGANIZAÇÃO DAS NAÇÕES UNIDAS. Human Rights Council. Trafficking in persons, especially women and children. Resolution 11/3. Eleventh Session. Disponível em: < http://www.un.org/womenwatch/daw/vaw/humanrights/A_HRC_RES 11 3.pdf>. Acesso em 14 outubro 2012.
} 


\section{CAPÍTULO 3 - O CONTEÚDO DAS OBRIGAÇÕES ESTATAIS NO TRÁFICO INTERNACIONAL DE PESSOAS A PARTIR DAS DIRETRIZES DEFINIDAS NO PROTOCOLO DE PALERMO}

A partir das premissas acima delineadas, nota-se que o Direito Internacional claramente permite a responsabilização estatal a partir da conduta de agentes privados, o que figura como essencial no caso do tráfico de pessoas, tendo em vista que esta prática é primordialmente desenvolvida por grupos criminosos, seja com ou sem a tolerância do Estado.

Contudo, para além de verificar se a um Estado pode ou não ser imputada a conduta de atores não estatais, importa ainda determinar quais são as obrigações específicas a que os Estados encontram-se vinculados, ou pelo menos um conjunto mínimo de obrigações, a fim de indicar um caminho de atuação a ser seguido.

A tarefa de esclarecer as obrigações estatais é de especial relevância considerando que ainda há muita incerteza e divergência no cenário internacional sobre o que os Estados devem ou não fazer no que diz respeito ao tráfico de seres humanos ${ }^{89}$. Diante deste fato é que se passará a analisar, à luz do Protocolo de Palermo, as obrigações estatais relacionadas a esta prática.

O Protocolo de Palermo estatui nos termos de seu artigo $2^{\circ}$, três linhas de atuação a serem seguidas pelos Estados, com a concomitante adoção de medidas para cada uma delas. São elas: prevenir e combater o tráfico; proteger e ajudar as vítimas, respeitando plenamente os seus direitos

\footnotetext{
${ }^{89}$ GALLAGUER, Anne. The International Law of Human Trafficking. First paperback edition. New York: Cambridge University Press, 2012. p. 7.
} 
humanos; e promover a cooperação entre os Estados Partes de forma a atingir esses objetivos ${ }^{90}$.

As três diretrizes de atuação elegidas constituem-se em obrigações dirigidas aos Estados Partes daquele instrumento, que operam de modo a impor condutas positivas ou negativas que se desenvolvam em consonância com os escopos acima delineados. Ademais, relacionam-se, diretamente, ao amplamente difundido paradigma dos "3Ps", atinente à "prevention of the human trafficking, the protection of the victims, and the prosecution of traffickers "91, que serviu de base para o desenvolvimento de inúmeros instrumentos internacionais e regionais na matéria, a exemplo da Convenção sobre a Luta contra o Tráfico de Seres Humanos, elaborada no âmbito do Conselho Europeu.

\subsection{Da diretriz de prevenção e combate}

A primeira diretriz refere-se à prevenção e combate do tráfico de pessoas, prestando atenção especial às mulheres e crianças.

\subsection{1 - Do dever de prevenir a ocorrência do tráfico de pessoas}

No que diz respeito à prevenção, o conteúdo da primeira diretriz definida pelo Protocolo do Tráfico pode parecer, em uma primeira leitura, muito claro. Ocorre que o tráfico é um fenômeno tão complexo que ainda não se tem definido de forma exata quais são as suas causas ${ }^{92}$, o que faz com que o objetivo de se definir quais são as obrigações específicas dos Estados neste âmbito específico ganhe certo grau de dificuldade.

\footnotetext{
${ }^{90}$ Art. $2^{\text {o: }}$ Os objetivos do presente Protocolo são os seguintes: a) Prevenir e combater o tráfico de pessoas, prestando uma atenção especial às mulheres e às crianças; b) Proteger e ajudar as vítimas desse tráfico, respeitando plenamente os seus direitos humanos; e c) Promover a cooperação entre os Estados Partes de forma a atingir esses objetivos.

91 BRUCKMULLER, Karin; SCHUMANN Stefan. Crime Control versus Social Work Approaches in the Context of the "3P" Paradigm. In: WINTERDYK, John; BENJAMIN Perrin; REICHEL Philip (Org.). Human Trafficking: Exploring the International Nature, Concerns, and Complexities. $1^{\text {a }}$ ed..Florida: CRC Press, 2012. p. 104.

92 GALLAGUER, Anne. The International Law of Human Trafficking. First paperback edition. New York: Cambridge University Press, 2012. p. 414.
} 
Para se determinar ao menos um conjunto mínimo de obrigações, no entanto, partirei da premissa de que, geralmente, a tarefa da prevenção visa combater as origens desta prática, e, nesta ordem de ideias, que as causas mais frequentemente citadas, são as desigualdades socioeconômicas entre os países, que colocam uma enorme quantidade de pessoas em situação de vulnerabilidade, e, portanto, como potenciais vítimas; a demanda por produtos e serviços advindos do tráfico; e a criação ou manutenção de um ambiente que facilite a atuação dos traficantes e seus cúmplices com impunidade $\mathrm{e}^{93}$.

\section{a) A situação de vulnerabilidade das vítimas de tráfico de pessoas}

A começar pela prevenção através do combate às causas de vulnerabilidade das vítimas, as alíneas a e b do artigo $9^{\circ},(1)^{94}$, do Protocolo do Tráfico determinam, expressamente, a necessidade do estabelecimento de políticas abrangentes e outras medidas de prevenção e proteção às vítimas, inclusive contra nova vitimização. No mesmo artigo também é feita referência a fatores como a pobreza, desigualdade, subdesenvolvimento, e falta de oportunidades, como propiciadores da vulnerabilidade daqueles que são atingidos por este fenômeno ${ }^{95}$.

É de suma importância ressaltar que as disposições do referido Protocolo apresentam caráter obrigatório, não sendo, portanto, uma mera sugestão de atuação na qual os Estados devem pautar-se. Alguma medida nesse sentido deve ser adotada por parte dos países que a estas disposições

\footnotetext{
${ }^{93}$ Ibid. p. 414.

${ }^{94}$ Art. 9: (1): Os Estados Partes estabelecerão políticas abrangentes, programas e outras medidas para: a) Prevenir e combater o tráfico de pessoas; b) Proteger as vítimas de tráfico de pessoas, especialmente as mulheres e as crianças, de nova vitimação.

${ }^{95}$ Art. 9: [...] (4): Os Estados Partes tomarão ou reforçarão as medidas, inclusive mediante a cooperação bilateral ou multilateral, para reduzir os fatores como a pobreza, o subdesenvolvimento e a desigualdade de oportunidades que tornam as pessoas, especialmente as mulheres e as crianças, vulneráveis ao tráfico.
} 
encontram-se vinculados, ${ }^{96}$ caso contrário, não restam dúvidas que deste descumprimento pode resultar sua responsabilidade.

No mesmo sentido, a Convenção do Conselho da Europa Relativa à Luta contra o Tráfico de Seres Humanos ${ }^{97}$, doravante Convenção Europeia sobre o Tráfico, criada no contexto do Conselho Europeu, nos termos de seu artigo $5^{\circ}$, e, a Convenção das Nações Unidas contra o Crime Organizado Transnacional $^{98}$, que estatui em seu artigo 31, (7), a necessidade de atuação dos Estados "sobre os fatores que tornam os grupos socialmente marginalizados vulneráveis à sua ação".

Como exemplo políticas e programas eficazes a serem empreendidos para prevenir o tráfico de seres humanos estão: pesquisas e levantamento de informações, sensibilização e campanhas de educação, iniciativas sociais e econômicas, e, programas de formação, em especial para as pessoas vulneráveis e para os profissionais envolvidos com o tráfico de seres humanos 99 .

Como se pode constatar, inúmeros instrumentos internacionais e regionais, dentre os quais se pode citar também a Convenção Interamericana sobre Tráfico Internacional de Menores ${ }^{100}$, apresentam previsões específicas relativas ao dever de prevenir. Tal circunstância acaba por permitir, caso este dever seja violado, a imposição de responsabilidade ao Estado de forma direta, desde que a violação possa ser a ele atribuída.

\footnotetext{
${ }^{96}$ GALLAGUER, Anne. The International Law of Human Trafficking. First paperback edition. New York: Cambridge University Press, 2012. p. 416.

97 CONSELHO EUROPEU. Convenção sobre a Luta contra o Tráfico de Seres Humanos. Disponível em : < http://conventions.coe.int/Treaty/EN/Treaties/Html/197.htm>. Acesso em: 03 outubro 2012.

98 BRASIL. Decreto n. 5.017, de 12 de março de 2004. Promulga o Protocolo Adicional à Convenção das Nações Unidas contra o Crime Organizado Transnacional Relativo à Prevenção, Repressão e Punição do Tráfico de Pessoas, em Especial Mulheres e Crianças. Disponível em: < http://www.planalto.gov.br/ccivil_03/_ato2004-2006/2004/decreto/d5017.htm >. Acesso em 11 setembro 2012.

${ }^{99}$ Artigo $5^{\circ}$ da Convenção Europeia sobre o Tráfico.

100 OEA. Convenção Interamericana sobre Tráfico Internacional de Menores. Disponível em: <http://www.oas.org/juridico/portuguese/treaties/B-57.htm>. Acesso em: 04 outubro 2012.
} 
Não apenas em tratados e convenções, porém, se encontra prevista a referida obrigação. Pronunciamentos de órgãos como os da ONU, e decisões de cortes e comitês internacionais e regionais, reforçam esse aspecto, ainda que sejam apenas indicativos de como os Estados devam agir, ou que, no máximo, possam servir como fonte interpretativa, situação na qual uma obrigação já existente para um determinado Estado é analisada à luz de tais pronunciamentos e decisões.

No caso já mencionado, Rantsev v. Chipre e Rússia, a Corte Europeia de Direitos Humanos, ao ressaltar a importância da adoção de uma abordagem global no combate ao tráfico, destaca não só a necessidade de prevenir esta prática, como também do seu desenvolvimento em conjunto com medidas de proteção às vítimas e punição dos traficantes. Segundo a Corte somente através da combinação destes três aspectos o combate ao tráfico se daria de forma efetiva ${ }^{101}$.

Os Princípios e Diretrizes Recomendadas pelas Nações Unidas sobre Direitos Humanos e Tráfico de Pessoas ${ }^{102}$, elaborado no âmbito do Alto Comissário das Nações Unidas para os Direitos Humanos, explicita bem o teor da obrigação de prevenir no que concerne à questão da posição de vulnerabilidade das vítimas. Em sua diretriz de número 7, dentre outras medidas, estabelece a melhora no acesso das crianças à educação, em especial para as meninas; a garantia de que os potencias migrantes, especialmente mulheres, sejam informados sobre os riscos da imigração; e o desenvolvimento de campanhas de informação para o público em geral sobre os perigos associados ao tráfico.

Também não pode deixar de ser mencionado que inúmeros fatores que contribuem para a vulnerabilidade das vítimas do tráfico estão

\footnotetext{
${ }^{101}$ CORTE EDH. Rantsev v. Cyprus and Rusia. Sentença de 7 de janeiro de 2010, par. 285. 102 ORGANIZAÇÃO DAS NAÇÕES UNIDAS. Princípios e Diretrizes Recomendadas pelas Nações Unidas sobre Direitos Humanos e Tráfico de Pessoas. Disponível em: < http://www1.umn.edu/humants/instree/traffickingGuidelinesHCHR.html\#\#7>. Acesso em: 04 outubro 2012.
} 
fortemente ligados a dimensões de gênero. Sucede que por estar esta questão tão sedimentada nas relações sociais, frequentemente não é enfrentada como causa real da situação de vulnerabilidade.

A Recomendação Geral $n^{\circ} 19$, sobre violência contra a mulher do Comitê para a Eliminação de todas as Formas de Discriminação contra a Mulher (CEDAW), é categórica ao afirmar que a pobreza e o desemprego aumentam as chances do tráfico de mulheres ${ }^{103}$. Este mesmo comitê, em outra oportunidade, revela ainda a sua preocupação diante das medidas insuficientes para o enfrentamento da desigualdade de gênero, questão que coloca como sendo uma das principais causas do tráfico ${ }^{104}$.

Neste aspecto, existe um entendimento crescente na comunidade internacional a respeito de qual seria a atuação necessária para que a vulnerabilidade ao tráfico relacionada à violência contra a mulher e à discriminação de gênero fosse enfrentada. Entre as medidas exigidas por parte dos Estados estão: a reforma da legislação discriminatória ou que é falha em combater a violência contra a mulher, o treinamento de agentes especializados nas questões de violência contra a mulher, e a implementação de iniciativas de educação e conscientização da população no que concerne a violência e discriminação contra a mulher ${ }^{105}$.

Outro grupo especialmente vulnerável ao tráfico, mas em relação ao qual já não se questiona o fato de que os Estados possuem a obrigação especial de combater as causas de sua vulnerabilidade, é o das crianças ${ }^{106}$. Um dos principais instrumentos utilizados como parâmetro para definir o

\footnotetext{
${ }^{103}$ CEDAW. General Recommendation No. 19 (llth session, 1992). Disponível em: < http://www.un.org/womenwatch/daw/cedaw/recommendations/recomm.htm >. Acesso em: 04 outubro 2012.

${ }^{104}$ CEDAW. Concluding observations of the Committee on the Elimination of Discrimination against Women. CEDAW/C/ARM/CO/4/Rev.1. Disponível em:< http://daccess-ddsny.un.org/doc/UNDOC/GEN/N09/229/31/PDF/N0922931.pdf?OpenElement>. Acesso em: 04 outubro 2012.

${ }^{105}$ GALLAGUER, Anne. The International Law of Human Trafficking. First paperback edition. New York: Cambridge University Press, 2012. p. 425.

${ }^{106}$ Ibid. p. 427.
} 
conteúdo das obrigações estatais, não só neste aspecto, mas em tudo ao que concerne ao tráfico de crianças, é a Convenção sobre os Direitos da Criança $^{107}$. Dispõe o artigo 35 da referida Convenção:

Os Estados Partes tomarão todas as medidas de caráter nacional, bilateral e multilateral que sejam necessárias para impedir o sequestro, a venda ou o tráfico de crianças para qualquer fim ou sob qualquer forma.

Embora adstrita ao âmbito do sistema interamericano de proteção, cabe destacar a Convenção Interamericana sobre Tráfico Internacional de Menores, que apresenta um regramento específico para o caso de tráfico dos menores de dezoito anos de idade. As diretrizes norteadoras desta Convenção podem ser resumidas em: garantir a proteção ao menor, levando em consideração os seus interesses superiores; instituir entre os Estados Partes um sistema de cooperação jurídica que consagre a prevenção e a sanção do tráfico internacional de menores, bem como adotar disposições jurídicas e administrativas sobre a matéria com essa finalidade; e assegurar a pronta restituição da criança vítima ao Estado onde tenha residência habitual. ${ }^{108}$

No tocante à proteção da criança os Estados devem pautar-se sempre na busca de seus melhores interesses, o que significa, sob um aspecto, garantir às crianças os direitos que lhe são peculiares em razão de sua condição e também os direitos reconhecidos aos adultos de uma forma mais efetiva.

As meninas, crianças abandonadas, órfãos, crianças em zonas de conflito, e as crianças que fazem parte de minorias raciais ou étnicas, são especialmente vulneráveis ao tráfico ${ }^{109}$, sendo esta também uma circunstância que não pode passar despercebida por parte dos Estados em

\footnotetext{
${ }^{107}$ ORGANIZAÇÃO DAS NAÇÕES UNIDAS. Convenção sobre os Direitos da Criança. Disponível em: <http://www2.ohchr.org/english/law/crc.htm> Acesso em 17 outubro 2012.

${ }_{108}$ OEA. Convenção Interamericana sobre Tráfico Internacional de Menores. Disponível em: <http://www.oas.org/juridico/portuguese/treaties/B-57.htm>. Acesso em: 04 outubro 2012.

${ }^{109}$ GALLAGUER, Anne. The International Law of Human Trafficking. First paperback edition. New York: Cambridge University Press, 2012. p. 429.
} 
relação às crianças que se encontrem sob sua jurisdição. Neste sentido se posiciona a Relatoria Especial sobre a venda de crianças, prostituição infantil e pornografia infantil da ONU, que, em uma de suas recomendações ${ }^{110}$, conclui que tendo as crianças pertencentes a minorias menos oportunidades de acesso aos serviços sociais básicos e à proteção, são mais vulneráveis ao tráfico, venda de crianças e à exploração sexual.

Outro instrumento utilizado com o intuito de definir o conteúdo das obrigações estatais no tocante ao tráfico internacional de crianças é o Protocolo Facultativo à Convenção sobre os Direitos da Criança relativo à venda de crianças, prostituição e pornografia infantis ${ }^{111}$, que no que diz respeito à luta contra as causas do tráfico de crianças, assim dispõe em seu artigo $10^{\circ},(3)$ :

Os Estados Partes deverão promover o reforço da cooperação internacional a fim de lutar contra as causas profundas, nomeadamente a pobreza e o subdesenvolvimento, que contribuem para que as crianças se tornem vulneráveis aos fenômenos da venda de crianças, prostituição, pornografia e turismo sexual infantis ${ }^{112}$.

Embora o enfrentamento dos problemas que propiciam a vulnerabilidade das vítimas do tráfico seja, ao menos formalmente, uma questão prioritária para todos os países $^{113}$, a prevenção deste fenômeno ainda toca outros dois importantes pontos: a demanda, e a criação ou manutenção de um ambiente que facilite a atuação dos traficantes e seus cúmplices com impunidade ${ }^{114}$.

\section{b) A demanda que fomenta o tráfico de pessoas}

110 ORGANIZAÇÃO DAS NAÇÕES UNIDAS. Assembleia Geral. Informe de la Relatora Especial sobre la venta de niños, la prostitución infantil y la utilización de niños en la pornografia. A/65/221. 4 de agosto de 2010. Disponível em <http://www.ungift.org/doc/knowledgehub/doc/knowledgehub/OHCHR/OHCHR_Special_Rappor teur_on the sale of_children_General_Assembly_spanish.pdf>. Acesso em: 27 agosto 2012.

${ }^{111}$ GALLAGUER, Anne. Op. Cit., p. 427.

${ }^{112}$ ORGANIZAÇÃO DAS NAÇÕES UNIDAS. Protocolo Facultativo para Convenção sobre os Direitos da Criança relativo à venda de crianças, prostituição e pornografia infantis. Disponível em: <http://www.unicef.org/brazil/pt/resources_10123.htm>. Acesso em: 04 outubro 2012.

${ }^{113}$ The GALLAGUER, Anne. The International Law of Human Trafficking. First paperback edition. New York: Cambridge University Press, 2012. p. 421.

${ }^{114}$ Ibid. p 427. 
A demanda tem relação com aqueles que, em última análise, usam ou se beneficiam dos serviços prestados pelos sujeitos traficados ${ }^{115}$. Pode ser dividida em duas espécies diferentes. A demanda de empregadores por trabalho barato e explorável, e a demanda dos consumidores por produtos e serviços produzidos ou fornecidos pelas pessoas traficadas. Também podem ser incluídas na lista da demanda, outras pessoas que tenham o mesmo objetivo de exploração com o intuito de receber algum benefício, como recrutadores, transportadores das vítimas de tráfico, e agentes públicos corruptos que sejam condescendentes, em troca de alguma vantagem ${ }^{116}$.

Para além das causas da demanda, a sua análise, com o intuito de verificação da possibilidade de imputação de responsabilidade a um Estado, deve pressupor também a pergunta sobre de que maneira os Estados, através de sua ação ou omissão, propiciam o consumo ou exploração dos produtos ou serviços advindos do tráfico ${ }^{117}$. Sendo um país de origem, trânsito, ou de destino do tráfico, a participação do Estado na geração de demanda pode assumir diferentes facetas, e com isso, resultar na imputação de responsabilidade por diferentes razões.

A título de exemplo, um país de destino pode estar alimentando a demanda do tráfico ao contar com uma legislação extremamente desprotetiva no que diz respeito ao trabalho estrangeiro, tendo em vista que se beneficia diretamente de tal circunstância, e, na mesma situação, um país de origem, pode, por exemplo, depender muito, do ponto de vista econômico, das remessas de seus trabalhadores ao exterior, e, assim, não

\footnotetext{
115 ORGANIZAÇAO DAS NAÇÕES UNIDAS. 2004 World Survey on the role of women in development. A/59/287/Add.1 ST/ESA/294. New York, 2006. Disponível em: 〈http://www.un.org/womenwatch/daw/public/WorldSurvey2004-Women\&Migration.pdf〉. Acesso em:04 outubro 2012.

${ }^{116}$ GALLAGUER, Anne. The International Law of Human Trafficking. First paperback edition. New York: Cambridge University Press, 2012. p. 432.

${ }^{117}$ GALLAGUER, Anne. The International Law of Human Trafficking. First paperback edition. New York: Cambridge University Press, 2012. Apud: ANDERSON, Bridget; O'CONNEL DAVIDSON, Julia. Trafficking: A Demand-Led Problem? p. 5.
} 
interferir em tal sistema, mesmo diante de evidencias de que alguns de seus cidadãos estão sendo explorados ${ }^{118}$.

Embora a obrigação de combater a demanda deva ser imputada primeiramente ao país onde a exploração ocorre, o país de origem e de trânsito também se encontram vinculados às obrigações advindas do tráfico, sendo a de combater os fatores que aumentam a vulnerabilidade das vítimas, apenas uma delas ${ }^{119}$. Isto é, nestas três situações, seja como um país de origem, trânsito, ou destino, o Estado estará violando um dever autônomo de combater a demanda do tráfico, o que ensejará a sua responsabilização nos termos da obrigação assumida.

O Protocolo do Tráfico enfrenta a questão da demanda ao estatuir que os Estados Partes:

Adotarão ou reforçarão as medidas legislativas ou outras, tais como medidas educacionais, sociais ou culturais, inclusive mediante a cooperação bilateral ou multilateral, a fim de desencorajar a procura que fomenta todo o tipo de exploração de pessoas, especialmente de mulheres e crianças, conducentes ao tráfico ${ }^{120}$.

No mesmo sentido, a Convenção Europeia sobre o Tráfico dispõe que:

To discourage the demand that fosters all forms of exploitation of persons, especially women and children, that leads to trafficking, each Party shall adopt or strengthen legislative, administrative, educational, social, cultural or other measures $[\ldots]^{121}$.

Como medidas mínimas a serem adotadas, este instrumento estabelece, por exemplo, a sensibilização para a responsabilidade e o papel desempenhado pela mídia e pela sociedade civil na identificação da demanda como uma das causas do tráfico de seres humanos; a realização de campanhas de informação envolvendo, conforme o caso, autoridades

\footnotetext{
${ }^{118}$ GALLAGUER, Anne. Op. cit., p. 434.

${ }^{119}$ GALLAGUER, Anne. The International Law of Human Trafficking. First paperback edition. New York: Cambridge University Press, 2012. p. 438.

${ }^{120}$ Artigo 9, (5) do Protocolo de Palermo.

${ }^{121}$ Artigo $6^{\circ}$ da Convenção Europeia sobre o Tráfico.
} 
públicas e políticos; e a adoção de medidas preventivas, incluindo programas de educação para meninos e meninas durante a sua escolaridade, que destaquem a natureza inaceitável de discriminação baseada no sexo ${ }^{122}$.

No ponto, merecem destaque os Princípios e Diretrizes Recomendadas pelas Nações Unidas sobre Direitos Humanos e Tráfico de Pessoas ${ }^{123}$, que atentam, especificamente, para a questão da demanda por produtos e serviços produzidos pelo tráfico para afirmar a necessidade de combate por parte dos Estados dos fatores que a geram. Tanto no aludido instrumento como no Protocolo do Palermo, a obrigação de reduzir a demanda não está adstrita apenas ao tráfico para fins de exploração sexual, mas para o combate de toda a demanda que resulta em alguma prática de exploração enquadrada como atividade fim do tráfico ${ }^{124}$.

A discriminação com base no gênero e na raça são outros aspectos que devem ser tidos como prioritários no enfrentamento da demanda que fomenta o tráfico, haja vista que também refletem em sua geração. As mulheres são mais vulneráveis a certas formas de exploração, porque vistas como menos propensas a afirmar-se e reivindicar seus direitos do que os homens. De igual modo, certos grupos étnicos ou raciais, com base em pressupostos racistas e culturais, também são preferidos como alvo da exploração relacionada ao tráfico ${ }^{125}$.

Diante desse quadro, com o intuito de cumprir sua obrigação de reduzir a demanda os Estados devem, então, atentar para o combate de atitudes e pensamentos de origem discriminatória, em especial contra

\footnotetext{
${ }^{122}$ Artigo $6^{\circ}$ da Convenção Europeia sobre o Tráfico.

123 Princípio 4 dos Princípios e Diretrizes Recomendadas pelas Nações Unidas sobre Direitos Humanos e Tráfico de Pessoas.

${ }^{124}$ GALLAGUER, Anne. The International Law of Human Trafficking. First paperback edition. New York: Cambridge University Press, 2012. p. 438.

${ }^{125}$ Ibid. p. 438.
} 
mulheres e migrantes. ${ }^{126}$ É preciso que os Estados atentem para leis e políticas em vigor que atuem de modo a reforçar discriminação ${ }^{127}$.

Ainda em relação ao combate da demanda por produtos e serviços advindos do tráfico, surge uma importante e recente questão a respeito de sua criminalização. Embora não trate o Protocolo de Palermo sobre o tema, o seu guia legislativo de implementação, o Guia Legislativo para a aplicação da Convenção das Nações Unidas contra o Crime Organizado Transnacional e seus Protocolos ${ }^{128}$, aponta para uma possível criminalização das práticas daqueles que intencionalmente se utilizam ou tiram algum proveito dos serviços das vítimas do tráfico ${ }^{129}$.

No mesmo sentido, a Convenção Europeia sobre o Tráfico ${ }^{130}$, em seu artigo 19, estabelece que:

Each Party shall consider adopting such legislative and other measures as may be necessary to establish as criminal offences under its internal law, the use of services which are the object of exploitation as referred to in Article 4 paragraph a of this Convention, with the knowledge that the person is a victim of trafficking in human beings.

Ou seja, criminalizar as referidas práticas não possui ainda o caráter de obrigação, no entanto, já se discute, com base nos instrumentos supracitados, a respeito de uma norma emergente com este conteúdo ${ }^{131}$. Também pelo fato de que a criminalização do uso de serviços das vítimas

\footnotetext{
${ }^{126}$ Ibid. p. 438.

${ }^{127}$ Ibid. p. 439.

${ }^{128}$ ORGANIZAÇÃO DAS NAÇOES UNIDAS. Guia Legislativo para a aplicação da Convenção das Nações Unidas contra o Crime Organizado Transnacional e seus Protocolos. Disponível em: <http://www.unodc.org/pdf/crime/legislative_guides/03\%20Legislative\%20guide_Trafficking\%20 in\%20Persons\%20Protocol.pdf >. Acesso em: 29 agosto 2012

${ }^{129}$ Nos termos do Guia Legislativo para a implementação do Protocolo de Palermo: [...] Another area is demand reduction, which could be achieved in part through legislative or other measures targeting those who knowingly use or take advantage of the services of victims of

Exploitation.

${ }^{130}$ CONSELHO EUROPEU. Convenção sobre a Luta contra o Tráfico de Seres Humanos. Disponível em: < http://conventions.coe.int/Treaty/EN/Treaties/Html/197.htm>. Acesso em: 03 outubro 2012.

${ }^{131}$ GALLAGUER, Anne. The International Law of Human Trafficking. First paperback edition. New York: Cambridge University Press, 2012. p. 441.
} 
poderia assegurar, em tese, a punição de indivíduos envolvidos diretamente no tráfico.

\section{c) A criação ou manutenção de um ambiente que facilite a atuação dos traficantes e seus cúmplices com impunidade}

$\mathrm{O}$ último aspecto da prevenção encontra-se relacionado à proibição da criação ou manutenção de um ambiente que facilite a atuação dos traficantes e seus cúmplices com impunidade, o que se dá, também, por meio da corrupção de agentes públicos.

A corrupção é geralmente definida como o mau uso do poder público para lograr a obtenção de algum proveito pessoal. Recentemente, esta prática passou a ser relacionada às violações de direitos humanos, e hoje, já é amplamente reconhecido que possui um papel de extrema importância no tráfico de pessoas ${ }^{132}$.

Ela se verifica a partir do envolvimento ativo, ou pelo menos do consentimento, de agentes públicos, que permitem desde o cruzamento de fronteiras internacionais de indivíduos vítimas do tráfico, até a manutenção destes indivíduos nas mais variadas situações de exploração. A corrupção se revela ainda na impunidade de que gozam os traficantes e seus cúmplices, vez que esta é propiciada, em grande medida, pelo desvio na atuação dos agentes públicos ${ }^{133}$.

Afastar a corrupção do âmbito da prática do tráfico de pessoas é tão importante quanto combater as causas da vulnerabilidade das vítimas e a demanda em si. O tráfico tornou-se muito atrativo para os traficantes considerado o contexto no qual eles já operam sabendo que poderão tirar proveito da corrupção de agentes públicos, até mesmo em relação à atuação

\footnotetext{
${ }^{132}$ Ibid. p. 442

${ }^{133}$ Ibid. p. 443.
} 
policial, e que a possibilidade de punição por suas ações é extremamente baixa $^{134}$.

Nota-se, portanto, que se faz imperiosa a revisão da legislação interna dos Estados no que concerne à corrupção, de modo a assegurar que o tráfico de pessoas se torne, ao mesmo tempo, menos atraente e mais difícil para os traficantes ${ }^{135}$.

\section{A Convenção contra o Crime Organizado Transnacional ${ }^{136}$ estatui,} em seu artigo $8^{\text {o137 }}$, a obrigatoriedade de criminalização da corrupção e, em seu artigo $9^{\circ}$, (1), traz a necessidade de adoção de medidas de ordem legislativa, administrativa, ou de outra ordem, para promover a integridade, e para prevenir, detectar, e punir, a corrupção de agentes públicos.

No intuito de dotar de mais efetividade a referida previsão, o aludido instrumento estabelece que sempre deverá ser assegurado às autoridades encarregadas da prevenção, detecção, e repressão da corrupção de agentes públicos, independência suficiente para impedir qualquer influência indevida em sua atuação. ${ }^{138}$ Ao se referir às sanções aplicáveis à prática da corrupção, a serem estabelecidas nos termos da legislação interna dos Estados, determina que deverá ser levada em consideração a gravidade da conduta perpetrada ${ }^{139}$.

\footnotetext{
${ }^{134}$ SKINNER, Robyn; MAHER, Catherine. Child Trafficking and Organized Crime. Where Have All the Young Girls Gone? p. 4. Disponível em: < http://www.yapi.org/rpchildtrafficking.pdf>. Acesso em: 07outubro 2012.

135 Ibid. p. 4.

${ }^{136}$ BRASIL. Decreto n. 5.015, de 12 de março de 2004. Promulga a Convenção das Nações Unidas contra o Crime Organizado Transnacional. Disponível em: <http://www.planalto.gov.br/ccivil_03/_ato2004-2006/2004/decreto/d5015.htm >. Acesso em 04 outubro 2012.

${ }^{137}$ Art. $8^{\circ}$ : 1. Cada Estado Parte adotará as medidas legislativas e outras que sejam necessárias para caracterizar como infrações penais os seguintes atos, quando intencionalmente cometidos: a) Prometer, oferecer ou conceder a um agente público, direta ou indiretamente, um benefício indevido, em seu proveito próprio ou de outra pessoa ou entidade, a fim de praticar ou se abster de praticar um ato no desempenho das suas funções oficiais; b) Por um agente público, pedir ou aceitar, direta ou indiretamente, um benefício indevido, para si ou para outra pessoa ou entidade, a fim de praticar ou se abster de praticar um ato no desempenho das suas funções oficiais.

${ }^{138}$ Art. 9.2 da Convenção das Nações Unidas contra o Crime Organizado Transnacional.

${ }^{139}$ Art. 11.1 da Convenção das Nações Unidas contra o Crime Organizado Transnacional.
} 
Outro instrumento que pode ser adotado como parâmetro para fins de determinação do conteúdo da obrigação de prevenção neste terceiro aspecto é a Convenção Europeia sobre o Tráfico. Embora não traga em suas previsões qualquer menção ao vocábulo corrupção, prevê expressamente, no que diz respeito à criminalização do tráfico de pessoas ${ }^{140}$, a obrigatoriedade do estabelecimento de circunstâncias que agravem a pena, dentre as quais se encontra a hipótese do cometimento de tráfico por funcionário público no desempenho de suas funções ${ }^{141}$.

Reforçando a obrigação acima, estabelece a diretriz 4.3 dos Princípios e Diretrizes das Nações Unidas sobre o Tráfico de Pessoas, que, sempre que necessário, a legislação deve prever circunstâncias agravantes de modo a serem aplicadas sanções adicionais às pessoas que são culpadas de tráfico, incluindo, em tais hipóteses, o tráfico de crianças, e o cometido por, ou tendo como cúmplices, funcionários do Estado.

Sem deixar de reconhecer a devida importância dos dispositivos acima mencionados, cabe destacar, ainda no que toca à corrupção, a Convenção das Nações Unidas contra a Corrupção, atualmente o mais abrangente documento internacional sobre o tema ${ }^{142}$. Adotando um regramento específico sobre a corrupção, este documento atenta, já em seu preâmbulo, para o vínculo existente entre a corrupção e outras formas de delinquência, dentre as quais menciona, expressamente, o crime organizado, a corrupção econômica, e a lavagem de dinheiro.

A referida Convenção encara a corrupção como um problema que deixou de ser local para assumir feições transnacionais ${ }^{143}$, e nesse sentido, traz a obrigação de que os Estados atuem em uma necessária cooperação

\footnotetext{
${ }^{140}$ Artigo 18 da Convenção Europeia sobre o Tráfico.

141 Artigo 24, c, da Convenção Europeia sobre o Tráfico.

142 ORGANIZAÇÃO DAS NAÇÕES UNIDAS. Convenção das Nações Unidas contra a Corrupção. Disponível em: < http://www.unodc.org/pdf/brazil/ConvONUcorrup_port.pdf $>$. Acesso em: 04 outubro 2012.

${ }_{143}$ GALLAGUER, Anne. The International Law of Human Trafficking. First paperback edition. New York: Cambridge University Press, 2012. p. 445.
} 
internacional na prevenção, combate, investigação, e responsabilização dos ofensores $^{144}$. Ademais, embora contemple as hipóteses de corrupção por parte de agentes públicos, seu âmbito de regulação se estende para além destas situações, abarcando também a corrupção no setor privado, tanto a nível nacional quanto internacional ${ }^{145}$. Destarte, sua aplicação se faz possível às varias formas de corrupção relacionada ao tráfico de pessoas, sendo, neste aspecto, mais protetiva do que a Convenção contra o Crime organizado Transnacional ${ }^{146}$.

\subsection{2 - Do dever de combater o trafico de pessoas}

Em outra direção, a primeira diretriz explicitada no Protocolo de Palermo aborda a necessidade de combater esse crime. Já tendo sido enfrentada a questão do combate no que se refere à luta contra as raízes do tráfico, passarei a analisar os aspectos atinentes à repressão desta prática, a exemplo da investigação e punição de seus perpetradores.

Partindo do ponto que já é amplamente aceito na comunidade internacional a imprescindibilidade de se criminalizar, investigar, processar, e, apropriadamente, punir os perpetradores do tráfico de pessoas ${ }^{147}$, resta explicitar o conteúdo mínimo de tais obrigações, e em que medida elas se impõem aos Estados.

Diante do panorama atual, no qual o índice de impunidade identificado no tráfico de pessoas é extremamente alto; os exploradores e traficantes são raramente investigados e processados; e as vítimas, quando

\footnotetext{
${ }^{144}$ Art. $1^{\circ}$ : A finalidade da presente Convenção é: a) Promover e fortalecer as medidas para prevenir e combater mais eficaz e eficientemente a corrupção; b) Promover, facilitar e apoiar a cooperação internacional e a assistência técnica na prevenção e na luta contra a corrupção, incluída a recuperação de ativos; c) Promover a integridade, a obrigação de render contas e a devida gestão dos assuntos e dos bens públicos.

${ }^{145}$ GALLAGUER, Anne. The International Law of Human Trafficking. First paperback edition. New York: Cambridge University Press, 2012. p. 446.

${ }^{146}$ Ibid. p. 446.

${ }^{147}$ GALLAGUER, Anne. The International Law of Human Trafficking. First paperback edition. New York: Cambridge University Press, 2012. p. 370.
} 
identificadas, são frequentemente criminalizadas ${ }^{148}$; buscar uma resposta dos Estados a partir de uma justiça criminal que, também nesse aspecto, priorize os direitos das vítimas, e que busque o fim de tamanha impunidade, deve ser tido como estratégia prioritária.

\section{a) Da obrigação de criminalizar o tráfico de pessoas}

O combate ao tráfico pressupõe, em um primeiro plano, a sua criminalização no sistema legal doméstico dos Estados. Dispõem nesse sentido, as previsões do Protocolo de Palermo, ${ }^{149}$ da Convenção Europeia sobre o Tráfico de Pessoas ${ }^{150}$, e os Princípios e Diretrizes das Nações Unidas sobre o Tráfico de Pessoas ${ }^{151}$, dentre outros instrumentos ${ }^{152}$.

Este dever, no entanto, precisa estar de acordo com a definição legal internacional, isto é, certas características fundamentais da definição do crime de tráfico, a partir do direito internacional, devem ser respeitadas, sendo certo que nenhum Estado encontra-se obrigado a reproduzir a descrição contida nos tratados internacionais e outros instrumentos ${ }^{153}$.

Nesse contexto, não estão cumprindo o referido mandamento aqueles Estados cuja lei interna não distingue precisamente entre o tráfico de crianças e adultos, e que apenas criminaliza o tráfico para fins de exploração sexual, ou o tráfico de mulheres e crianças ${ }^{154}$. A criminalização deve ser estabelecida independentemente da existência de um elemento transnacional $^{155}$.

\footnotetext{
${ }^{148}$ Ibid. p. 370.

149 Artigo 7 do Protocolo de Palermo.

${ }^{150}$ Artigo 18 da Convenção Europeia sobre o Tráfico.

151 Princípio 12 dos Princípios e Diretrizes Recomendadas pelas Nações Unidas sobre Direitos Humanos e Tráfico de Pessoas.

${ }^{152}$ A título de exemplo, a Convenção para a Eliminação de todas as Formas de Discriminação contra a Mulher, e a Convenção sobre os Direitos da Criança também apontam nesse sentido.

${ }^{153}$ GALLAGUER, Anne. The International Law of Human Trafficking. First paperback edition. New York: Cambridge University Press, 2012. p. 373.

${ }^{154}$ Ibid. p. 374.

155 Artigo 34, (2), da Convenção das Nações Unidas contra o Crime Organizado Transnacional e artigo 18 da Convenção Europeia sobre o Tráfico.
} 
A previsão acerca da responsabilização de pessoas jurídicas, e a punição da tentativa e da cumplicidade, tendo em vista que como perpetradores devem ser igualmente considerados aqueles que instigam a prática do tráfico $^{156}$, também são elementos a serem levados em conta a fim de que o combate ao tráfico se dê de forma efetiva.

De acordo com o Protocolo de Palermo, cada Estado Parte adotará medidas legislativas e outras que considere necessárias para estabelecer como infrações penais a tentativa e a participação como cúmplice ${ }^{157}$. No entanto, considerando a natureza do tráfico de pessoas, a possibilidade de responsabilização de pessoas jurídicas também merece destaque.

O tráfico é cometido, primordialmente, por organizações criminosas que em grande medida atuam através de empresas e corporações comerciais ${ }^{158}$. Desse modo, se os Estados não contarem com mecanismos que tornem capazes a imputação de responsabilidade a estas pessoas, esta prática não estará sendo reprimida, mas sim incentivada, em razão do baixo risco que representa para os criminosos.

Sobre o tema da responsabilização das pessoas jurídicas, embora o Protocolo do Tráfico seja silente, já existem previsões na Convenção contra o Crime Organizado Transnacional ${ }^{159}$ e na Convenção Europeia sobre o Tráfico $^{160}$.

\footnotetext{
156 BRUCKMULLER, Karin; SCHUMANN Stefan. Crime Control versus Social Work Approaches in the Context of the "3P" Paradigm. In: igaório, John; BENJAMIN Perrin; REICHEL Philip (Org.). Human Trafficking: Exploring the International Nature, Concerns, and Complexities. 1 ${ }^{\text {a }}$ ed..Florida: CRC Press, 2012. p. 108.

${ }^{157}$ Artigo 5.2 do Protocolo de Palermo.

${ }^{158}$ GALLAGUER, Anne. The International Law of Human Trafficking. First paperback edition. New York: Cambridge University Press, 2012. p. 375.

159 Art. 10: 1. Cada Estado Parte adotará as medidas necessárias, em conformidade com o seu ordenamento jurídico, para responsabilizar pessoas jurídicas que participem em infrações graves envolvendo um grupo criminoso organizado e que cometam as infrações enunciadas nos Artigos 5, 6,8 e 23 da presente Convenção [...].

${ }^{160}$ Art. 22: 1. Each Party shall adopt such legislative and other measures as may be necessary to ensure that a legal person can be held liable for a criminal offence established in accordance with this Convention, committed for its benefit by any natural person, acting either individually or as part of an organ of the legal person, who has a leading position within the legal person, based on:
} 
No mesmo sentido, os Princípios e Diretrizes das Nações Unidas sobre o Tráfico de Pessoas dispõem que os Estados devem considerar: a aprovação de legislação administrativa, civil, e penal, acerca da responsabilidade de pessoas jurídicas pelo crime de tráfico, e ainda devem considerar rever as leis e condições para o licenciamento e operação de empresas que possam servir de cobertura para o tráfico, como agências matrimoniais, agências de emprego, agências de viagens, hotéis, e serviços de acompanhante ${ }^{161}$.

Ainda no que toca ao conteúdo da proibição legal internacional do crime de tráfico de pessoas, é preciso ressaltar que a obrigação de criminalização de condutas elementares do tipo de tráfico, nos termos dos instrumentos sobre o tema, ainda não é uma norma com caráter obrigatório. Em que pese o tráfico, sendo um crime complexo, implique na violação de uma série de condutas proibidas do ponto de vista do direito internacional, tanto a partir de previsões em tratados específicos como a partir de regras costumeiras, a exemplo da proibição da escravidão, do trabalho forçado, e da tortura, os tratados específicos sobre tráfico ainda não exigem a criminalização destas condutas relacionadas ${ }^{162}$.

Desse modo, a falha de um Estado em criminalizar estas situações apenas significará a violação de uma obrigação internacional se estas vierem estabelecidas nos termos de um tratado específico ou do direito internacional costumeiro. Não obstante, os Princípios e Diretrizes das Nações Unidas sobre o Tráfico de Pessoas encorajam a criminalização das condutas elementares ou relacionadas ao tráfico ${ }^{163}$.

(a) a power of representation of the legal person; (b) an authority to take decisions on behalf of the legal person; (c) an authority to exercise control within the legal person [...].

161 Diretriz 4.2 dos Princípios e Diretrizes Recomendadas pelas Nações Unidas sobre Direitos Humanos e Tráfico de Pessoas.

${ }^{162}$ GALLAGUER, Anne. The International Law of Human Trafficking. First paperback edition. New York: Cambridge University Press, 2012. p. 376.

163 Diretriz 4.1 dos Princípios e Diretrizes das Nações Unidas sobre o Tráfico de Pessoas: Amending or adopting national legislation in accordance with international standards so that the crime of trafficking is precisely defined in national law and detailed guidance is provided as to its 
Outra perspectiva da criminalização a ser destacada é o uso dos serviços de uma vítima de tráfico. O Protocolo de Palermo também é omisso neste ponto, contudo, a Convenção Europeia sobre o Tráfico dispõe que cada Estado Parte deve considerar a adoção de medidas legislativas, e outras que sejam necessárias, para estabelecer como infrações penais em seu direito interno, a utilização de serviços que sejam objeto de exploração relacionada ao tráfico, desde que haja o conhecimento de que a pessoa é vítima de tráfico de seres humanos ${ }^{164}$.

Ainda que existam disposições como a acima mencionada e também um crescente reconhecimento de que os usuários dos serviços de tráfico são uma parte crítica do problema, de modo que a falha em criminalizar esse aspecto da cadeia do tráfico pode implicar na ineficácia da criminalização como um todo, a criminalização do uso dos serviços das vítimas de tráfico não é, atualmente, uma obrigação internacional estabelecida ${ }^{165}$.

\section{b) Da obrigação de investigar e processar as violações de direitos relacionadas ao tráfico}

$\mathrm{O}$ segundo aspecto a ser considerado no que se refere ao combate do tráfico de pessoas é o dever de investigar e processar. As obrigações de investigar e processar são aplicáveis tanto em relação às violações cometidas por agentes investidos na função pública como por atores privados, e como mencionado anteriormente, também devem ser exercidas em conformidade com a devida diligência ${ }^{166}$.

Sobre o tema, manifestou-se a Corte Europeia de Direitos, no já citado caso Rantsev v. Chipre e Rússia. De acordo com este Tribunal, um procedimento investigatório efetivo, e de acordo com a devida diligência,

various punishable elements. All practices covered by the definition of trafficking such as debt bondage, forced labour and enforced prostitution should also be criminalized.

${ }^{164}$ Artigo 19 da Convenção Europeia sobre o Tráfico.

165 GALLAGUER, Anne. The International Law of Human Trafficking. First paperback edition. New York: Cambridge University Press, 2012. p. 378.

${ }^{166}$ GALLAGUER, Anne. The International Law of Human Trafficking. First paperback edition. New York: Cambridge University Press, 2012. p. 382. 
deve incluir investigadores dotados de independência, não apenas institucional, mas prática; deve ser realizada com presteza; e ser capaz de conduzir à identificação e punição dos responsáveis. ${ }^{167}$

Os Estados devem assegurar que as investigações, ou a repressão de infrações, não dependam da denúncia ou da acusação feita por uma vítima $^{168}$, pelo menos quando o crime foi cometido no todo ou em parte do seu território ${ }^{169}$.

Outro aspecto referente à obrigação de investigar e processar, imposto em obediência ao dever de devida diligência, diz respeito à existência de agentes treinados e especializados para lidar com o tráfico, tanto em sua prevenção como combate. Nesse sentido, o Protocolo de Palermo ${ }^{170}$, e a Convenção Europeia sobre o Tráfico ${ }^{171}$, que assim dispõe:

Each Party shall provide or strengthen training for relevant officials in the prevention of and fight against trafficking in human beings, including Human Rights training. The training may be agency-specific and shall, as appropriate, focus on: methods used in preventing such trafficking, prosecuting the traffickers and protecting the rights of the victims, including protecting the victims from the traffickers.

A disponibilização de agentes treinados para enfrentar o tráfico perpassa a implementação de programas especiais de treinamento tanto para policiais, que precisam ser alertados sobre a gravidade deste crime e treinados para melhor identificar os traficantes, como para o Judiciário, com o objetivo de sensibilizar os juízes para a presença de vítimas de tráfico entre os réus $^{172}$.

Por derradeiro, destaque-se que é preciso integrar perspectivas de gênero tanto em relação à obrigação de investigar quanto à de processar. Os

\footnotetext{
${ }^{167}$ CORTE EDH. Rantsev v. Cyprus and Rusia. Sentença de 7 de janeiro de 2010, par. 233.

168 CORTE EDH. Rantsev v. Cyprus and Rusia. Sentença de 7 de janeiro de 2010, par. 288.

169 Artigo 27. 1 da Convenção Europeia sobre o Tráfico.

${ }^{170}$ Artigo 10.2 do Protocolo de Palermo.

${ }^{171}$ Artigo 29.3 da Convenção Europeia sobre o Tráfico.

${ }^{172}$ ORGANIZAÇAO DAS NAÇÕES UNIDAS. 2004 World Survey on the role of women in development. A/59/287/Add.1 ST/ESA/294. New York, 2006. Disponível em: <http://www.un.org/womenwatch/daw/public/WorldSurvey2004-Women\&Migration.pdf >. Acesso em:04 outubro 2012.
} 
Estados devem assegurar a promoção da igualdade entre os sexos e a integração deste aspecto no desenvolvimento, implementação, e avaliação das medidas que adotarem ${ }^{173}$. Isto é, devem ser considerados não só os problemas específicos das mulheres ${ }^{174}$, como, também, as particularidades relacionadas ao tráfico de homens e meninos ${ }^{175}$.

\section{c) Da obrigação de impor sanções efetivas e proporcionais}

Além das obrigações de criminalizar, investigar, e processar, encontra-se estabelecido o dever de impor sanções efetivas e proporcionais ao tráfico de pessoas. ${ }^{176}$ As penas previstas e aplicadas no âmbito interno dos Estados, ao mesmo tempo em que dissuadem o cometimento de tal prática, precisam ser proporcionais aos danos ocasionados e aos benefícios $\operatorname{auferidos}^{177}$.

Nesse sentido, os Estados devem considerar o estabelecimento de sanções adicionais a serem aplicadas às pessoas que são culpadas de tráfico por circunstâncias agravantes, como as relacionados ao tráfico de crianças, ou a delitos cometidos ou envolvendo a cumplicidade de agentes estatais ${ }^{178}$. Ademais, medidas também devem ser adotadas no intuito de permitir o confisco dos instrumentos e produtos do tráfico, garantindo, sempre que possível, que os rendimentos sejam usados para o benefício das vítimas ${ }^{179}$.

\subsection{Da diretriz de proteção das vítimas de tráfico de pessoas}

Combater a vulnerabilidade de potenciais vítimas é uma forma de proteção diante das violações que são cometidas no âmbito do tráfico de

\footnotetext{
173 Artigo 17 da Convenção Europeia sobre o Tráfico.

174 . Artigo 10.(2) do Protocolo de Palermo.

175 GALLAGUER, Anne. The International Law of Human Trafficking. First paperback edition. New York: Cambridge University Press, 2012. p. 389.

${ }^{176}$ Ibid. p. 392.

${ }^{177}$ Ibid. p. 392.

178 Diretriz 4.3 dos Princípios e Diretrizes Recomendadas pelas Nações Unidas sobre Direitos Humanos e Tráfico de Pessoas.

${ }^{179}$ ORGANIZAÇAO DAS NAÇÕES UNIDAS. 2004 World Survey on the role of women in development. A/59/287/Add.1 ST/ESA/294. New York, 2006. Disponível em: <http://www.un.org/womenwatch/daw/public/WorldSurvey2004-Women\&Migration.pdf $>$. Acesso em:04 outubro 2012.
} 
pessoas. Em verdade, porém, está longe se ser o suficiente. Outros obstáculos e dificuldades se verificam no que toca à questão do tratamento das vítimas já traficadas, e que exigem uma atenção especial por parte dos Estados onde esta prática se verifica.

À semelhança de outras obrigações, em que pese a existência de um consenso a respeito da necessidade de proteção das vítimas do tráfico, os contornos e limites impostos a partir desta obrigação também não se encontram, ainda, claramente definidos. ${ }^{180}$

Ocorre que, se no passado havia uma maior relutância por parte dos Estados no reconhecimento destas obrigações, desde a década passada, já se pode constatar um considerável progresso nesse aspecto. A conscientização acerca dos sérios abusos sofridos pelas vítimas do tráfico, as repercussões políticas de ser visto internacionalmente como um país que responde de modo apropriado ao tráfico, e o reconhecimento do papel fundamental que as vítimas desempenham para que se logre uma investigação efetiva com a consequente punição dos perpetradores, são alguns dos fatores responsáveis por esta mudança. ${ }^{181}$

Hoje, já é possível identificar, a partir de instrumentos internacionais e regionais, bem como no âmbito interno dos países, um núcleo de deveres estatais no que diz respeito ao tratamento e proteção das vítimas de tráfico $^{182}$.

\section{a) Da obrigação de identificação das vitimas}

A primeira obrigação a ser imposta aos Estados, no sentido de que deve ser observada anteriormente às demais, é a obrigação de identificação das vítimas. Como já mencionado anteriormente, com a elaboração do Protocolo de Palermo, as vítimas do tráfico passaram a ser todos os seres

\footnotetext{
${ }^{180}$ GALLAGUER, Anne. The International Law of Human Trafficking. First paperback edition. New York: Cambridge University Press, 2012. p. 276.

${ }^{181}$ Ibid. p. 276.

${ }^{182}$ Ibid. p. 276.
} 
humanos submetidos a esta prática. Tal mudança, no entanto, ainda não fornece respostas a todas as dificuldades existentes na identificação de uma vítima de tráfico.

Seja diante da falta de compromisso dos Estados, que simplesmente não aceitam o fato da existência de pessoas traficadas em seus territórios, ou porque falta ao Estado estrutura, no sentido de recursos e conhecimento do tema, que o permita realizar uma identificação destas pessoas, fato é que muitas vítimas de tráfico não são identificadas, o que resulta em sua completa invisibilidade. Outras vezes, embora sua situação chegue ao conhecimento do Estado, normalmente, são identificadas como migrantes ilegais ou provenientes de contrabando ${ }^{183}$.

Apesar de existirem características que distinguem a migração ilegal e o contrabando de migrantes da prática do tráfico de pessoas, muitas vezes, estes elementos diferenciadores não são facilmente detectados na prática, $o$ que faz com que as vítimas do tráfico sejam em um primeiro momento identificadas como imigrantes ilegais ou vítimas de contrabando, para apenas posteriormente, após uma investigação mais apurada, vir a ser constatado que se trata, em verdade, de vítimas de tráfico de pessoas. ${ }^{184}$

Ocorre que é de extrema relevância a identificação de uma pessoa como vítima de tráfico, tendo em vista que os direitos assegurados ao indivíduo traficado são muito diferentes daqueles atribuídos aos migrantes em situação irregular, frequentemente chamados de "migrantes ilegais"185, a exemplo dos migrantes contrabandeados.

A título de ilustração, no que diz respeito aos migrantes contrabandeados, diferentemente do Protocolo de Palermo que estabelece ${ }^{186}$ que cada Estado Parte considerará a possibilidade da adoção de medidas

\footnotetext{
${ }^{183}$ Ibid. p. 278

${ }^{184}$ GALLAGUER, Anne. The International Law of Human Trafficking. First paperback edition. New York: Cambridge University Press, 2012. p. 278.

${ }^{185}$ Ibid. p. 278.

${ }^{186}$ Artigo $7^{\circ}$, (1) do Protocolo de Palermo.
} 
que permitam às vítimas de tráfico de pessoas permanecerem em seu território de modo temporário ou permanente, o Protocolo contra o Crime Organizado Transnacional, relativo ao Combate ao Contrabando de Migrantes por via terrestre, marítima e aérea ${ }^{187}$ não apresenta qualquer disposição nesse sentido $^{188}$.

Em relação aos migrantes que se encontram em situação irregular, mas que não tenham sido contrabandeados, a prática internacional revela que, geralmente, não se beneficiam nem do conjunto mínimo de proteção assegurado aos que são identificados como migrantes contrabandeados ${ }^{189}$.

Assim, em vista disso, e também porque a identificação das vítimas constitui-se no primeiro passo para a sua efetiva proteção, é que o cumprimento deste dever por parte dos Estados faz-se tão necessário.

Em que pese a importância da aludida obrigação, neste ponto, o Protocolo de Palermo não traz qualquer imposição aos Estados. A Convenção Europeia sobre o Tráfico, em outra direção, impõe, expressamente, este dever aos Estados Partes. Reconhece como vítimas de tráfico, e, portanto, como sujeitos protegidos pelas suas disposições, qualquer pessoa que as autoridades competentes tenham motivos razoáveis para acreditar que tenha sido uma vítima de tráfico de seres humanos ${ }^{190}$. Em seu artigo 10, a Convenção aduz, também, que os Estados devem garantir a necessária proteção legal e a disponibilização de pessoal qualificado para o processo de identificação.

No que diz respeito aos Estados que não fazem parte da Convenção Europeia, suas disposições não são vinculativas. No entanto, sendo a identificação o primeiro passo no processo de proteção e garantia de direitos às vítimas, a obrigatoriedade da adoção de medidas positivas no

187 O referido Protocolo, assim como o Protocolo de Palermo, também é complementar à Convenção das Nações Unidas contra o Crime Organizado Transnacional.

${ }^{188}$ GALLAGUER, Anne. The International Law of Human Trafficking. First paperback edition. New York: Cambridge University Press, 2012. p. 278.

${ }^{189}$ Ibid. p. 279.

${ }^{190}$ Artigo 10.2 da Convenção Europeia sobre o Tráfico. 
intuito de identificar as vítimas torna-se evidente. Assegurar a devida proteção às vítimas de tráfico torna-se impossível se não houver, em um primeiro momento, a identificação de quem são os sujeitos destinatários de proteção ${ }^{191}$, de modo que não há outra saída senão elevar a identificação das vítimas do tráfico ao caráter de obrigação.

Reforçando a referida obrigação, os Princípios e Diretrizes das Nações Unidas sobre o Tráfico a trazem, expressamente, em sua diretriz número 2. Dispõe o referido documento:

[...] A failure to identify a trafficked person correctly is likely to result in a further denial of that person's rights. States are therefore under an obligation to ensure that such identification can and does take place.

Sobre o assunto, cabe destacar ainda a jurisprudência da Corte Europeia de Direitos Humanos, segundo a qual os Estados têm a obrigação de garantir formação adequada para os profissionais que atuam em áreas relevantes relacionadas à identificação das vítimas ${ }^{192}$, bem como de proporcionar a formação necessária para os funcionários de imigração ${ }^{193}$.

\section{b) Da obrigação de não criminalização e não detenção}

Outro aspecto relevante no que toca à proteção das vítimas de tráfico é o da não criminalização e não detenção. É comum em muitos países a detenção, e até mesmo a acusação e submissão a um processo, das pessoas traficadas. Esse tratamento é justificado a partir de razões que vão desde a necessidade de resguardá-las contra danos adicionais, ao desempenho de atividades consideradas ilícitas nos países de destino, como o ingresso ilegal no país, o trabalho ilegal, e a prostituição, que acabam sendo atividades fins para as quais foram traficadas. Muitas vezes, a criminalização e a detenção acabam ocorrendo como consequência da falta de uma identificação correta, como vítima de tráfico, e nesse contexto, as leis de imigração acabam sendo um fator contributivo, assim como países

${ }^{191}$ GALLAGUER, Anne. The International Law of Human Trafficking. First paperback edition. New York: Cambridge University Press, 2012. p. 282.

${ }_{192}$ CORTE EDH. Rantsev v. Cyprus and Rusia. Sentença de 7 de janeiro de 2010, par. 296.

${ }^{193}$ CORTE EDH. Rantsev v. Cyprus and Rusia. Sentença de 7 de janeiro de 2010, par. 287. 
de origem que penalizam as vítimas pelo seu retorno ou por sua saída desautorizada $^{194}$.

No que concerne à criminalização das pessoas traficadas por ofensas relacionadas ao seu status o Protocolo do Tráfico não traz qualquer previsão. No entanto, desde sua adoção, já pode ser identificado um movimento no sentido da rejeição desta prática pelos Estados. Em uma Conferência dos Estados Partes da Convenção contra o Crime Organizado Transnacional foi recomendado aos Estados que considerassem, em sua legislação doméstica, não punir ou processar pessoas traficadas por atos ilícitos que decorressem, diretamente, de sua situação como vítima de tráfico $^{195}$.

A Convenção Europeia sobre o Tráfico, por exemplo, apresenta disposição nesse sentido:

Each Party shall, in accordance with the basic principles of its legal system, provide for the possibility of not imposing penalties on victims for their involvement in unlawful activities, to the extent that they have been compelled to do so. ${ }^{196}$

De forma mais ampla, os Princípios e Diretrizes das Nações Unidas sobre o Tráfico de pessoas estabelecem a não detenção, não acusação, e não submissão a um processo, não apenas em relação às atividades que as pessoas traficadas tenham sido coagidas a desempenhar, mas também de forma a abarcar qualquer ato que tenha sido desempenhado como uma consequência direta do tráfico ${ }^{197}$.

Ressalte-se que os Estados apenas devem prever a possibilidade de não criminalização e de não submissão a um processo das pessoas traficadas ${ }^{198}$. Em caso de envolvimento destas em atividades que não

\footnotetext{
${ }^{194}$ GALLAGUER, Anne. The International Law of Human Trafficking. First paperback edition. New York: Cambridge University Press, 2012. p. 283.

${ }^{195}$ Ibid. p. 284.

${ }^{196}$ Artigo 26 da Convenção Europeia sobre o Tráfico.

197 Princípio 7 dos Princípios e Diretrizes Recomendadas pelas Nações Unidas sobre Direitos Humanos e Tráfico de Pessoas.

${ }_{198}$ GALLAGUER, Anne. The International Law of Human Trafficking. First paperback edition. New York: Cambridge University Press, 2012. p. 284.
} 
decorram diretamente do fato de terem sido traficadas, não há qualquer impedimento para tanto, de modo que o princípio da não criminalização por ofensas relacionadas ao status não implica em uma completa imunidade da vítima de tráfico ${ }^{199}$.

A detenção de sujeitos traficados em centros de imigração, abrigos, e outros locais ${ }^{200}$, tenham ou não sido identificadas como vítimas de tráfico $^{201}$, também é uma prática comum. Ainda que as justificativas invocadas sejam a necessidade de garantir a proteção e suporte, a proteção contra danos adicionais, razões de ordem pública, ou ainda, assegurar a sua cooperação na investigação e punição de traficantes, ${ }^{202}$ devem ser observados alguns cuidados nesse procedimento.

O Protocolo do Tráfico não apresenta qualquer disposição sobre este aspecto, mas existe previsão nos Princípios e Diretrizes das Nações Unidas sobre o Tráfico de Pessoas. Este documento estabelece que os Estados devem considerar garantir que as pessoas traficadas não sejam, em qualquer circunstância, mantidas na detenção de imigrantes ou sob outras formas de custódia ${ }^{203}$. Os Estados devem considerar assegurar, em cooperação com organizações não governamentais, a disponibilização de abrigo seguro, adequado, e que atenda às necessidades das pessoas traficadas $^{204}$. Determina ainda que a prestação de abrigo não pode estar condicionada à vontade das vítimas para prestar depoimento em processo penal $^{205}$.

Importa ressaltar que embora tais previsões não sejam dotadas de caráter mandatório, inobservar os requisitos para a aplicação da detenção

\footnotetext{
${ }^{199}$ Ibid. p. 288.

${ }^{200}$ Ibid. p. 283

${ }^{201}$ Ibid. p. 288.

${ }^{202}$ Ibid. p. 288.

203 Diretriz 2.6 dos Princípios e Diretrizes Recomendadas pelas Nações Unidas sobre Direitos Humanos e Tráfico de Pessoas.

204 Princípio 6.1 dos Princípios e Diretrizes Recomendadas pelas Nações Unidas sobre Direitos Humanos e Tráfico de Pessoas.

${ }^{205}$ Princípio 6.1 dos Princípios e Diretrizes Recomendadas pelas Nações Unidas sobre Direitos Humanos e Tráfico de Pessoas.
} 
constitui um desrespeito e uma interferência indevida em direitos como a liberdade de circulação, e a proibição de uma detenção arbitrária, estes sim, estabelecidos, expressamente, em documentos internacionais e regionais, a exemplo do Pacto Internacional sobre direitos civis e políticos, da Carta Africana dos Direitos do Homem e dos Povos, da Convenção Europeia de Direitos Humanos e da Convenção Americana de Direitos Humanos ${ }^{206}$.

O Comitê de Direitos Humanos da ONU já se pronunciou a respeito dos requisitos que devem se fazer presentes para que a detenção não constitua uma violação da liberdade de circulação. Esta deve estar prevista em lei, ser consistente com outros direitos, e deve ainda ser necessária em uma sociedade democrática para a proteção da pessoa ${ }^{207}$.

Quanto à detenção de vítimas de tráfico menores de dezoito anos, outros cuidados precisam ser tomados. Em especial no que toca a proteção contra danos adicionais, é essencial assegurar que seja nomeado um responsável legal capaz de identificar quais são os melhores interesses da

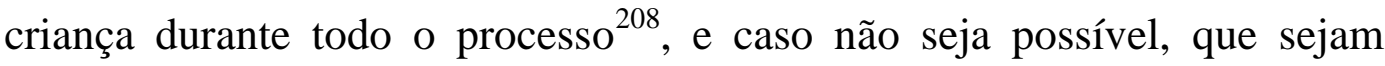
adotadas medidas para identificar e localizar os membros da família. Sempre que possível, devem ser tomadas medidas para facilitar o reencontro de crianças traficadas com suas famílias ${ }^{209}$.

A Convenção sobre os Direitos da Criança leciona que nenhuma criança deve ser privada de sua liberdade de forma ilegal ou arbitrária ${ }^{210}$. Sendo arbitrária, de acordo com o direito internacional, a detenção que

\footnotetext{
${ }^{206}$ GALLAGUER, Anne. The International Law of Human Trafficking. First paperback edition. New York: Cambridge University Press, 2012. p. 289.

${ }^{207}$ ORGANIZAÇÃO DAS NAÇÕES UNIDAS. Human Rights Committee (HRC). CCPR General Comment No. 27: Article 12 (Freedom of Movement), 2 November 1999, CCPR/C/21/Rev.1/Add.9. Disponível em: <http://www.unhcr.org/refworld/pdfid/45139c394.pdf>. Acesso em: 29 agosto 2012.

${ }^{208}$ GALLAGUER, Anne. The International Law of Human Trafficking. First paperback edition. New York: Cambridge University Press, 2012. p. 295.

209 Diretriz 8.4 dos Princípios e Diretrizes Recomendadas pelas Nações Unidas sobre Direitos Humanos e Tráfico de Pessoas.

${ }^{210}$ Art. 37: [...] b) nenhuma criança seja privada de sua liberdade de forma ilegal ou arbitrária. A detenção, a reclusão ou a prisão de uma criança serão efetuadas em conformidade com a lei e apenas com último recurso, e durante o mais breve período de tempo que for apropriado.
} 
desrespeita os melhores interesses da criança, que não é usada apenas como última alternativa, que não é imposta pelo período apropriado, que não separa crianças de adultos, e que não assegura a manutenção do contato com a família e de assistência legal, dentre outros aspectos ${ }^{211}$.

\section{c) Da desvinculação do oferecimento de proteção da obrigatoriedade de cooperação por parte das pessoas traficadas}

A disponibilização de proteção e suporte às vítimas também envolve outra questão de extrema relevância: a necessidade de desvinculação do oferecimento de proteção às pessoas traficadas da obrigatoriedade de cooperação por parte destas ${ }^{212}$. As consequências físicas e psicológicas geradas pelo tráfico são tão severas que chegam a constituir-se em verdadeiros traumas. Dessa maneira, condicionar a assistências às vítimas à sua colaboração através de informações e testemunhos durante os procedimentos criminais de seus exploradores seria uma forma continuada de violação de seus direitos. Seria revitimizá-las, ainda mais considerando que a sua colaboração, muitas vezes, pode resultar em retaliação e intimidação por parte dos perpetradores.

De fato, ainda que o aparato legal de alguns países estabeleça assistência incondicional, na prática, as vítimas ainda tendem a ser pressionadas a prover informações e testemunhar. Essa vinculação entre proteção e cooperação da vítima é algo que prevalece em todas as regiões do mundo. Contudo, já existe uma crescente aceitação a respeito da necessidade da separação destes dois aspectos ${ }^{213}$, o que se reflete em alguns documentos internacionais e regionais sobre o tráfico de pessoas.

De acordo com os Princípios e Diretrizes das Nações Unidas sobre o Tráfico de Pessoas, por exemplo, a prestação de abrigo não pode ficar condicionada à vontade das vítimas para prestar depoimento em eventual

${ }^{211}$ GALLAGUER, Anne. The International Law of Human Trafficking. First paperback edition. New York: Cambridge University Press, 2012. p. 296.

${ }^{212}$ Ibid. p. 298.

${ }^{213}$ Ibid. p. 299. 
processo penal ${ }^{214}$. Embora o Protocolo de Palermo não faça nenhuma menção expressa nesse sentido, o seu Guia Legislativo estabelece que o suporte e proteção às vítimas também não deve estar relacionado à capacidade ou vontade da vítima de cooperar com os procedimentos legais $^{215}$.

Nesse ponto, a Convenção Europeia sobre o Tráfico é expressa ao estatuir que:

Each Party shall adopt such legislative or other measures as may be necessary to ensure that assistance to a victim is not made conditional on his or her willingness to act as a witness ${ }^{216}$.

Ainda que, como já mencionado, as supracitadas previsões não sejam respeitadas na prática, confirmam uma evidência de que a obrigação existente para os Estados de fornecer assistência e proteção não pode, de maneira alguma, estar condicionada à contribuição das vítimas. ${ }^{217} \mathrm{~A}$ assistência se justifica em razão das violações a que foram submetidas e não em razão de se conseguir lograr uma investigação e punição dos perpetradores.

\section{d) Da proteção contra danos adicionais}

A proteção contra danos adicionais também pode ser identificada como um dever estatal em relação às pessoas traficadas que se encontrem sob a sua jurisdição.

Sobre o tema, o Protocolo de Palermo apenas prevê que os Estados Partes devem empregar esforços no intuito de garantir a segurança física das vítimas de tráfico, uma vez que estas se encontrem em seu território ${ }^{218}$. Como se pode notar, a natureza desta obrigação é frágil, pois ao exigir por

\footnotetext{
214 Diretriz 6.1 dos Princípios e Diretrizes Recomendadas pelas Nações Unidas sobre Direitos Humanos e Tráfico de Pessoas.

${ }^{215}$ GALLAGUER, Anne. The International Law of Human Trafficking. First paperback edition. New York: Cambridge University Press, 2012. p. 299.

${ }^{216}$ Artigo 12.6 da Convenção Europeia sobre o Tráfico.

217 GALLAGUER, Anne. Op. cit., p. 300.

${ }^{218}$ Artigo 6.5 do Protocolo de Palermo.
} 
parte dos Estados apenas esforços revela-se como um verdadeiro guia de conduta.

Contudo, em que pese a falta de caráter mandatório desta disposição, a partir do Guia Legislativo para a Convenção das Nações Unidas contra o Crime Organizado Transnacional e seus Protocolos ${ }^{219}$, fruto de um amplo processo participativo de instituições, representantes governamentais de todo o mundo, e também de inúmeros especialistas na matéria, pode ser claramente inferido um dever estatal de adotar pelo menos alguns algumas medidas no sentido de esforçar-se para proteger os sujeitos traficados $^{220}$.

Ainda que o Protocolo do Tráfico não seja tão protetivo, a Convenção Contra o Crime Organizado Transnacional dispõe, nesse contexto, que:

Cada Estado Parte, dentro das suas possibilidades, adotará medidas apropriadas para assegurar uma proteção eficaz contra eventuais atos de represália ou de intimidação das testemunhas que, no âmbito de processos penais, deponham sobre infrações previstas na presente Convenção e, quando necessário, aos seus familiares ou outras pessoas que lhes sejam próximas.

Dentre as medidas a serem adotadas para a proteção estão, por exemplo, a proteção física, a mudança de identidade e assistência na obtenção de empregos ${ }^{221}$. Não deve haver a divulgação pública da identidade das vítimas de tráfico e a sua privacidade deve ser respeitada e protegida, na medida do possível ${ }^{222}$.

Por tratar-se de uma interferência em sua privacidade, e que pode trazer implicações em suas chances de reintegração social e recuperação, as

\footnotetext{
${ }^{219}$ ORGANIZAÇÃO DAS NAÇOES UNIDAS. Guia Legislativo para a Convenção das Nações Unidas contra o Crime Organizado Transnacional e seus Protocolos.Disponível em: $<$ http://www.unodc.org/pdf/crime/legislative guides/03\%20Legislative\%20guide_Trafficking \%20 in\%20Persons\%20Protocol.pdf >. Acesso em: 29 agosto 2012

${ }^{220}$ Nesse sentido, o parágrafo 59 da Parte II do Guia Legislativo dispõe que: [...]Under the Protocol, each State party is obliged to actually take at least some steps that amount to an "endeavour" to protect safety.

${ }^{221}$ Artigo 28.2 da Convenção Europeia sobre o Tráfico.

222 Diretriz 6.6 dos Princípios e Diretrizes Recomendadas pelas Nações Unidas sobre Direitos Humanos e Tráfico de Pessoas.
} 
medidas adotadas para a proteção contra danos adicionais devem ser exercidas com o consentimento da vítima. ${ }^{223}$ Nesse sentido o artigo 6.1 do Protocolo de Palermo:

Nos casos em que se considere apropriado e na medida em que seja permitido pelo seu direito interno, cada Estado Parte protegerá a privacidade e a identidade das vítimas de tráfico de pessoas, incluindo, entre outras (ou inter alia), a confidencialidade dos procedimentos judiciais relativos a esse tráfico.

\section{e) Demais aspectos atinentes à proteção das vítimas de tráfico}

Também se enquadram nas medidas de suporte, fazendo-se imprescindíveis para o tratamento das vítimas, o cuidado e o apoio físico e psicológico. De acordo com o Protocolo de Palermo ${ }^{224}$ :

Cada Estado Parte terá em consideração a aplicação de medidas que permitam a recuperação física, psicológica e social das vítimas de tráfico de pessoas, incluindo, se for caso disso, em cooperação com organizações não governamentais, outras organizações competentes e outros elementos de sociedade civil.

Dentre as medidas para o fornecimento dessa espécie de assistência o Protocolo estipula, exemplificando, o fornecimento de alojamento adequado; aconselhamento e informação, especialmente quanto aos direitos que a lei lhes reconhece; assistência médica, psicológica e material; e, oportunidades de emprego, educação e formação. Sempre tendo em consideração as necessidades especiais de cada vítima no que se relaciona à idade, gênero, e outras particularidades ${ }^{225}$. Do mesmo modo que na proteção contra danos adicionais, como se trata, em última análise, de medidas de assistência, as vítimas também devem poder recusar o seu recebimento $^{226}$.

O direito ao acesso consular é outro desdobramento da diretriz de proteção das vítimas de tráfico, e que possui grande importância,

\footnotetext{
${ }^{223}$ GALLAGUER, Anne. The International Law of Human Trafficking. First paperback edition. New York: Cambridge University Press, 2012. p. 303.

${ }^{224}$ Artigo 6.3 do Protocolo de Palermo.

${ }^{225}$ GALLAGUER, Anne. The International Law of Human Trafficking. First paperback edition. New York: Cambridge University Press, 2012. p. 307.

${ }^{226}$ Ibid. p. 315.
} 
principalmente no que se relaciona com a prática de acusação e detenção destes sujeitos.

Embora não haja previsão específica em nenhum tratado a respeito do tráfico de pessoas ${ }^{227}$, os Princípios e Diretrizes das Nações Unidas sobre o Tráfico de Pessoas estabelecem, expressamente, que os Estados devem considerar assegurar que as pessoas traficadas sejam informadas sobre o seu direito de acesso aos representantes diplomáticos e consulares do seu Estado de nacionalidade. ${ }^{228}$

A Corte Interamericana de Direitos Humanos, no exercício de sua função consultiva, também já se manifestou sobre o assunto. A Corte adota o entendimento de que o direito ao acesso consular é aplicável em todos os casos em que um estrangeiro é privado de liberdade, e por qualquer $\operatorname{motivo}^{229}$.

Outrossim, a assistência legal se faz especialmente necessária para uma proteção efetiva das vítimas de tráfico. Em verdade, é um dos aspectos mais imprescindíveis, haja vista que é através dele que se concretizam outros importantes direitos que devem ser assegurados a estas pessoas ${ }^{230}$. Ela contempla o suporte no sentido de aconselhamento, e também o acesso à informação sobre os procedimentos legais ${ }^{231}$.

O Protocolo de Palermo estipula que cada Estado Parte deve assegurar que o seu sistema jurídico ou administrativo contenha medidas que forneçam às vítimas de tráfico, quando necessário, informações sobre procedimentos judiciais e administrativos aplicáveis ${ }^{232}$.

\footnotetext{
${ }^{227}$ Ibid. p. 311.

228 Diretriz 6.3 dos Princípios e Diretrizes Recomendadas pelas Nações Unidas sobre Direitos Humanos e Tráfico de Pessoas.

229 Corte I.D.H. Opinión Consultiva OC-16/99 de 1 de octubre de 1999.El Derecho a la Información sobre la Asistencia Consular en el Marco de las Garantías del Debido Proceso LegalSerie A No. 16, par. 101.

${ }^{230}$ GALLAGUER, Anne. The International Law of Human Trafficking. First paperback edition. New York: Cambridge University Press, 2012. p. 315.

${ }^{231}$ Ibid. p. 315.

${ }^{232}$ Artigo 6 do Protocolo de Palermo.
} 
Por conseguinte, não basta apenas a assistência e a disponibilização de informações acerca dos procedimentos legais. É necessário garantir também uma participação efetiva nesses procedimentos, assegurando que as opiniões e preocupações das pessoas traficadas sejam apresentadas e levadas em conta durante o processo penal instaurado contra os autores das infrações ${ }^{233}$.

Os Princípios e Diretrizes das Nações Unidas sobre o Tráfico de Pessoas confirmam o direito das vítimas de tráfico à assistência legal. Estipulam que os Estados devem considerar proporcionar às pessoas traficadas assistência jurídica e outras formas de assistência, em relação a quaisquer ações criminais, civis, ou outras, contra seus exploradores. Ademais, prevê que às vítimas devem ser fornecidas informações em uma linguagem que entendam ${ }^{234}$.

Cabe destacar também que a assistência legal deve vir acompanhada, em caso de vítimas que venham a prestar testemunho em procedimentos legais, de medidas de proteção contra retaliações e intimidações por parte dos traficantes. E caso seja necessário, essa proteção deve ser estendida aos familiares e outras pessoas próximas das vítimas. É o que dispõe o artigo 24, (1), da Convenção das Nações Unidas Contra o Crime Organizado Transnacional.

Em suma, os Estados devem garantir que os processos judiciais em que as pessoas traficadas estejam envolvidas não sejam prejudiciais para os seus direitos, dignidade ou bem-estar físico e psicológico ${ }^{235}$.

Por derradeiro, no que concerne à diretriz de proteção, é imperioso ressaltar que, não raramente, os sujeitos vitimizados pelo tráfico encontramse ilegais ou pendentes na regularização de seu status nos países de destino.

\footnotetext{
${ }^{233}$ Artigo 6.2 do Protocolo de Palermo. No mesmo sentido a Convenção das Nações Unidas contra o Crime Organizado Transnacional, em seu artigo 25, (3).

${ }^{234}$ Diretriz 6.5 dos Princípios e Diretrizes Recomendadas pelas Nações Unidas sobre Direitos Humanos e Tráfico de Pessoas.

${ }_{235}$ Diretriz 6.4 dos Princípios $e$ Diretrizes Recomendadas pelas Nações Unidas sobre Direitos Humanos e Tráfico de Pessoas.
} 
Diante deste fato, na ausência de previsões específicas que assegurem o seu direito de permanecer no país, ao menos temporariamente, não conseguem sequer participar nos procedimentos criminais contra seus exploradores, e muito menos desfrutar de medidas de proteção e assistência, haja vista que são logo deportados ${ }^{236}$.

Garantir o direito de permanência nos países de destino para as vítimas que não possuem o direito de permanecer legalmente assegurado faz-se imprescindível, também, caso o retorno para o país de origem possa significar o risco de ser traficado novamente ${ }^{237}$.

Assim, nos termos do Protocolo de Palermo, cada Estado é encorajado a considerar a possibilidade de adotar medidas legislativas, ou outras medidas adequadas, que garantam às vítimas o direito de permanecer em seu território a título temporário, ou permanente, se este for o caso ${ }^{238}$.

\subsection{Da diretriz de cooperação internacional}

A terceira diretriz estabelecida no Protocolo de Palermo se refere à promoção da cooperação entre os Estados Partes de forma a atingir os objetivos delineados nas outras duas diretrizes anteriormente abordadas: a de prevenir e combater o tráfico, e, a de proteger e ajudar as vítimas, respeitando plenamente os seus direitos humanos.

Embora exista a possibilidade do tráfico de pessoas ocorrer inteiramente dentro dos limites de um Estado, isto é, sem a manifestação de nenhum elemento transacional, a terceira diretriz se destina, precipuamente, aos casos de tráfico em que aspectos transnacionais se fazem presentes.

São situações nas quais os elementos desta prática, a exemplo das vítimas, evidências do crime, ou qualquer outro, se encontram localizados

\footnotetext{
${ }^{236}$ GALLAGUER, Anne. The International Law of Human Trafficking. First paperback edition. New York: Cambridge University Press, 2012. p. 320.

${ }^{237}$ Ibid. p. 321.

${ }^{238}$ Artigo 7 do Protocolo de Palermo.
} 
em mais de um país, ${ }^{239}$ necessitando, desse modo, da cooperação dos Estados nos quais qualquer um desses elementos se desenvolveu.

O tráfico de pessoas é um fenômeno regional e global, nem sempre podendo ser tratado eficazmente a nível nacional. A resposta em âmbito nacional pode resultar na fuga dos traficantes para outro local, e assim a cooperação internacional, multilateral e bilateral acaba por desempenhar um papel importantíssimo na luta contra as atividades desta prática ${ }^{240}$.

Ademais, destaque-se que os mecanismos através dos quais a cooperação internacional entre Estados pode se dar variam. Vão desde mecanismos formais, nos termos de vínculos legalmente estabelecidos, a mecanismos informais, que surgem, muitas vezes, em complementariedade aos primeiros ${ }^{241}$.

A extradição é uma das formas mais antigas através da qual a cooperação acontece ${ }^{242}$, sendo que, hoje, é normalmente desenvolvida a partir de tratados bilaterais ou multilaterais entre Estados ${ }^{243}$. Trata-se de um ato no qual, mediante solicitação prévia de um país que possui jurisdição em relação a um crime praticado, uma pessoa acusada ou já condenada pelo cometimento de tal crime, é entregue ao país que a reclama, para que seja, então, processada e eventualmente condenada e punida.

No que toca especificamente ao tráfico de pessoas, a extradição não é explicitada Protocolo de Palermo, porém, deve ser considerado o fato de que este documento deve ser interpretado em conjunto com a Convenção

\footnotetext{
${ }^{239}$ GALLAGUER, Anne. The International Law of Human Trafficking. First paperback edition. New York: Cambridge University Press, 2012. p. 404.

240 Diretriz 11 dos Princípios e Diretrizes Recomendadas pelas Nações Unidas sobre Direitos Humanos e Tráfico de Pessoas.

${ }^{241}$ GALLAGUER, Anne. Op. cit., p. 412.

${ }^{242}$ GALLAGUER, Anne. Op. cit., p. 404.

${ }^{243}$ DANDURAND, Yvon. International Cooperation. In: WINTERDYK, John; BENJAMIN Perrin; REICHEL Philip (Org.). Human Trafficking: Exploring the International Nature, Concerns, and Complexities. $1^{\mathrm{a}}$ ed..Florida: CRC Press, 2012. p. 219.
} 
das Nações Unidas contra o Crime Organizado Transnacional ${ }^{244}$, e que esta possui um artigo ${ }^{245}$ inteiramente destinado ao regramento desse mecanismo.

Dentre as disposições da referida Convenção cabe destacar o artigo 16.3, que inclui as infrações abrangidas por este instrumento (nas quais se enquadram os crimes perpetrados por organizações criminosas, a exemplo do tráfico de pessoas) entre aquelas que podem dar lugar à extradição estabelecida nos termos de qualquer tratado de extradição em vigor entre os Estados Partes; e, o artigo 16.4, que estabelece que se um Estado Parte que condicione a extradição à existência de tratado receber um pedido de extradição de outro Estado Parte com o qual não possua tratado, poderá considerar a Convenção como fundamento jurídico da extradição ${ }^{246}$.s

Em algumas situações, como, por exemplo, no caso de Estados que não extraditam seus nacionais, ou, a fim de evitar uma dupla punição em observância ao princípio do ne bis in idem, os Estados podem até se recusar a realizar a extradição ${ }^{247}$. Não obstante, diante dessas situações, instrumentos internacionais e regionais ${ }^{248}$ apresentam a obrigação de extraditar ou processar, impondo ao Estado que se recusar a extraditar o processamento do crime. É o que estabelecem os artigos 15.3 e $16.10^{249}$ da Convenção contra o Crime Organizado Transnacional, excetuando a hipótese da nacionalidade.

Ressalte-se ainda que artigo 16.8 da mesma Convenção estatui um compromisso adotado pelos Estados Partes de acelerar os processos de extradição e simplificar seus requisitos em matéria de prova no que

\footnotetext{
${ }^{244}$ Artigo 1.1 do Protocolo de Palermo.

245 Artigo 16 da Convenção das Nações Unidas contra o Crime Organizado Transnacional.

246 Com disposição semelhante a Convenção Interamericana sobre Tráfico Internacional de Menores, em seu artigo 10.

${ }^{247}$ GALLAGUER, Anne. The International Law of Human Trafficking. First paperback edition. New York: Cambridge University Press, 2012. p. 407.

${ }^{248}$ Neste sentido a Convenção Europeia sobre o Tráfico e o Protocolo Facultativo para Convenção sobre os Direitos da Criança relativo à venda de crianças, prostituição e pornografia infantis.

${ }^{249}$ Art. 16.10: Um Estado Parte em cujo território se encontre o presumível autor da infração, se não extraditar esta pessoa a título de uma infração à qual se aplica o presente Artigo pelo único motivo de se tratar de um seu cidadão [...].
} 
concerne às infrações abrangidas pela Convenção, revelando, com isso, o quão complexo o processo de extradição pode ser, e concomitantemente, a necessidade de se adotar medidas positivas ${ }^{250}$ a fim de que este procedimento seja realmente efetivo ${ }^{251}$.

Outro mecanismo de cooperação que se destaca no âmbito do tráfico de pessoas é a assistência legal mútua. Assim como a extradição é um procedimento formal, geralmente baseado em tratados bilaterais e multilaterais, e também na legislação nacional, que pode permitir a assistência mútua na ausência de um tratado. Essa forma de cooperação, no entanto, tem por objeto o auxílio recíproco entre governos com vistas a facilitar investigações e procedimentos criminais ${ }^{252}$.

Nos termos do artigo 18. 3 da Convenção das Nações Unidas contra o Crime Organizado Transnacional ${ }^{253}$, a cooperação jurídica prestada pode envolver, por exemplo, o recolhimento de testemunhos e depoimentos; o fornecimento de informações, elementos de prova, e pareceres de peritos; a realização de buscas e apreensões; e a facilitação do comparecimento voluntário de pessoas no Estado Parte requerente.

A referida Convenção ${ }^{254}$ prevê que os Estados Partes prestarão toda cooperação jurídica possível no que diz respeito às investigações, processos, e outros atos judiciais relacionados às infrações abrangidas por este documento.

\footnotetext{
${ }^{250}$ GALLAGUER, Anne. The International Law of Human Trafficking. First paperback edition. New York: Cambridge University Press, 2012. p. 404.

${ }^{251}$ DANDURAND, Yvon. International Cooperation. In: WINTERDYK, John; BENJAMIN Perrin; REICHEL Philip (Org.). Human Trafficking: Exploring the International Nature, Concerns, and Complexities. 1 ${ }^{\mathrm{a}}$ ed..Florida: CRC Press, 2012. p. 219.

${ }^{252}$ Ibid. p. 220.

${ }^{253}$ BRASIL. Decreto n. 5.015, de 12 de março de 2004. Promulga a Convenção das Nações Unidas contra o Crime Organizado Transnacional. Disponível em: 〈http://www.planalto.gov.br/ccivil_03/_ato2004-2006/2004/decreto/d5015.htm >. Acesso em 04 outubro 2012.

${ }^{254}$ Artigo 18.1 e 18.2 da Convenção das Nações Unidas contra o Crime Organizado Transnacional.
} 
A este respeito, já se manifestou a Corte Europeia de Direitos Humanos no anteriormente aludido caso Rantsev ${ }^{255}$, quando destacou a importância da assistência legal mútua para a realização de investigações. Nesta situação, a Corte considerou que o Estado do Chipre falhou em não realizar um pedido de assistência jurídica relacionado à colheita de depoimentos dos testemunhos de duas mulheres que trabalhavam com a vítima, Sra. Rantsev, em que pese a existência de tratados de cooperação nesse sentido. Nesse contexto, condenou o referido Estado pela violação do direito à vida por não ter empreendido uma investigação efetiva.

Demais disso, os Estados devem garantir, tanto em termos de extradição, quanto em termos de assistência legal mútua, que o pedido de cooperação seja necessário e razoável. Devem ser tidos em consideração os direitos e garantias processuais básicos do sujeito requerido através do sistema de cooperação, ou de terceiros, que por ela possam vir a ser $\operatorname{afetados}^{256}$.

Como já salientado, os mecanismos através do quais a cooperação é operada também podem ser informais, no sentido de que carecem de uma base legal estabelecida. A cooperação informal é utilizada, por exemplo, antes das investigações se tornaram oficiais, ou, antes do início de um processo judicial, em situações nas quais a busca de dados e outras informações através da estrutura formal de assistência mútua se faz muito lenta e complexa. ${ }^{257}$

Ou seja, a cooperação informal atua de modo a complementar e facilitar os regimes de cooperação formal, sendo certo que a decisão de adotar medidas com esse intuito é fruto da iniciativa dos próprios Estados. É o que prevê, a titulo de exemplo, os Princípios e Diretrizes Recomendadas pelas Nações Unidas sobre Direitos Humanos e

\footnotetext{
${ }^{255}$ CORTE EDH. Caso Rantsev v. Cyprus and Russia. Sentença de 7 de janeiro de 2010. par. 241.

${ }^{256}$ GALLAGUER, Anne. The International Law of Human Trafficking. First paperback edition. New York: Cambridge University Press, 2012. p. 412.

${ }^{257}$ Ibid. p.412.
} 
Tráfico de Pessoas ${ }^{258}$, e o artigo 19 da Convenção das Nações Unidas contra o Crime Organizado Transnacional ${ }^{259}$, que assim dispõe:

Os Estados Partes considerarão a possibilidade de celebrar acordos ou protocolos bilaterais ou multilaterais em virtude dos quais, com respeito a matérias que sejam objeto de investigação, processos ou ações judiciais em um ou mais Estados, as autoridades competentes possam estabelecer órgãos mistos de investigação. Na ausência de tais acordos ou protocolos, poderá ser decidida casuisticamente a realização de investigações conjuntas [...].

Em suma, existem muitas maneiras de tornar mais efetivo o combate ao tráfico de pessoas, sendo a cooperação internacional entre os Estados de forma a coordenar suas investigações e trocar informações, apenas uma delas. Como demonstrado, o direito internacional já reconhece a imprescindibilidade da adoção desse tipo de medida, que, hoje, já se encontra alçada ao caráter de obrigação, uma vez que regulada em tratados e, inclusive, reconhecida por cortes internacionais e regionais. Não obstante, a decisão de trabalhar mais estreitamente com outros Estados na repressão desse crime, ainda depende da respectiva capacidade e vontade política de cada país ${ }^{260}$, uma vez que decidam por ser Estados Partes de tratados com esse conteúdo, ou ainda, por cooperar informalmente.

\footnotetext{
258 Diretriz 11.6 e 11.7 dos Princípios e Diretrizes Recomendadas pelas Nações Unidas sobre Direitos Humanos e Tráfico de Pessoas.

259 BRASIL. Decreto n. 5.015, de 12 de março de 2004. Promulga a Convenção das Nações Unidas contra o Crime Organizado Transnacional. Disponível em: <http://www.planalto.gov.br/ccivil_03/ato2004-2006/2004/decreto/d5015.htm >. Acesso em 04 outubro 2012.

260 DANDURAND, Yvon. International Cooperation. In: WINTERDYK, John; BENJAMIN Perrin; REICHEL Philip (Org.). Human Trafficking: Exploring the International Nature, Concerns, and Complexities. 1a ed..Florida: CRC Press, 2012.p. 228.
} 


\section{CONCLUSÃO}

Como se pretendeu demonstrar ao longo do presente trabalho, podemos identificar um grande número de instrumentos e pronunciamentos, internacionais e regionais, que enfrentam, especificamente, a questão do tráfico internacional de pessoas.

O enfoque no combate ao tráfico é uma tendência que vem se verificando recentemente, verdadeiramente pautada no reconhecimento de que esta prática consiste em uma violação generalizada de direitos humanos, e que, assim sendo, deve ser prioritariamente combatida pelos Estados. A produção de inúmeros documentos internacionais e regionais sobre o tema, bem como o fato do tráfico de pessoas ter se tornado um assunto de grande relevância na agenda internacional, nada mais é que um reflexo de tal circunstância.

Não há dúvidas de que a melhor estratégia a ser adotada na luta contra este fenômeno consiste em uma abordagem holística, que contemple todos os seus aspectos. Diante dessa constatação é que foi desenvolvido o já mencionado paradigma dos "3P's" alusivos às diretrizes de prevenir, proteger as vítimas modo a respeitar os seus direitos humanos, e apropriadamente punir os traficantes.

Com efeito, nota-se, a constituição de uma forte base normativa internacional de proteção dos sujeitos traficados, ainda que em vias de crescimento e aperfeiçoamento. Normas que se analisadas em conjunto chegam a constituir um verdadeiro corpus iuris de proteção, tendo em vista que muitos dos aspectos decorrentes das diretrizes de prevenir, proteger e punir já se encontram alçados ao nível de obrigações, nos termos de tratados internacionais, ou mesmo a partir de decisões de cortes internacionais e regionais. 
Tais mudanças não podem deixar de ser reconhecidas como um avanço, no entanto, fato é que, diante do cenário atual, o que se reflete, em grande medida, nos dados estatísticos acerca do tema, muito ainda precisa ser feito.

Se por um lado, a possibilidade da imputação de responsabilidade internacional a um Estado a partir da conduta de agentes não estatais pode ser destacada como uma circunstância positiva para o enfrentamento desta prática, haja vista que esta se perpetua, primordialmente, a partir da conduta de agentes privados, seja com ou sem a aquiescência do Estado, por outro, muitos desafios ainda precisam ser superados.

Ainda pairam inúmeras incertezas no cenário internacional a respeito do conteúdo das obrigações estatais no tocante ao tráfico internacional de pessoas. Do ponto de vista do direito internacional, o que se perpetua também no âmbito do ordenamento jurídico interno dos Estados, muitos aspectos relativos ao tratamento do tráfico ainda não se encontram desenvolvidos a contento, no sentido de colaborar eficazmente com a luta contra este fenômeno.

Podem ser identificados dois problemas principais, que acabam, em grande medida, contribuindo com a perpetuação do tráfico. Primeiramente, a falta de disposições, no que se pode citar como exemplo o próprio Protocolo de Palermo. Uma vez cotejado com outros documentos internacionais sobre o tráfico, em que pese seja considerado o principal instrumento internacional na matéria, pode-se constatar que este documento é lacunoso em muitos aspectos que precisariam estar presentes se o que se busca é combater eficazmente o tráfico.

Em segundo lugar, o fato de que muitas previsões existentes no direito internacional sobre o tema, no que mais uma vez se inclui o Protocolo de Palermo, não são dotadas de caráter mandatório. Atuam, 
assim, como verdadeiros guias de conduta, a depender de fatores como a vontade política de cada Estado de segui-las ou não.

Tais circunstâncias atinentes ao tratamento normativo do tráfico de pessoas podem ser diretamente relacionadas com a insuficiência das ações estatais, indicando algumas das possíveis razões pelas quais esta prática vem atingindo proporções tão assustadoras. Não obstante, não pode deixar de ser destacado que passam ao largo de serem os únicos fatores que influenciam negativamente no que diz respeito à atuação dos Estados no tratamento e enfrentamento deste fenômeno. 


\section{REFERÊNCIAS BIBLIOGRÁFICAS}

AUSSERER, Caroline. Controle em nome da proteção: Análise dos discursos sobre o tráfico internacional de pessoas. Rio de Janeiro. 2007. 170 p. Dissertação de Mestrado - Instituto de Relações Internacionais da Pontifícia Universidade Católica do Rio de Janeiro.

BRUCKMULLER, Karin; SCHUMANN Stefan. Crime Control versus Social Work Approaches in the Context of the "3P" Paradigm. In: WINTERDYK, John; BENJAMIN Perrin; REICHEL Philip (Org.). Human Trafficking: Exploring the International Nature, Concerns, and Complexities. $1^{\mathrm{a}}$ ed..Florida: CRC Press, 2012. p. 103-126.

COMPARATO, Fábio Konder. A afirmação histórica dos direitos humanos. $6^{\mathrm{a}}$ ed..São Paulo: Saraiva, 2008. 577 p.

DANDURAND, Yvon. International Cooperation. In: WINTERDYK, John; BENJAMIN Perrin; REICHEL Philip (Org.). Human Trafficking: Exploring the International Nature, Concerns, and Complexities. $1^{\text {a }}$ ed..Florida: CRC Press, 2012. p.208 a 232.

GALLAGUER, Anne. The International Law of Human Traffickin. First paperback edition. New York: Cambridge University Press, 2012. 535 p.

MAZZUOLI, Valerio de Oliveira. Curso de Direito Internacional Público. $3^{a}$ ed.. São Paulo: Editora Revista dos Tribunais, 2008. 973 p.

REZEK, José Francisco. Direito Internacional Público: Curso Elementar. $11^{a}$ ed.. São Paulo: Saraiva, 2008. 415 p.

\section{Documentos Eletrônicos}

ARY, Thalita Carneiro. O tráfico de pessoas em três dimensões: evolução, globalização e a rota Brasil-Europa.Brasília.2009. 158 p. Dissertação de 
Mestrado - Instituto de Relações Internacionais da Universidade de Brasília.

Disponível

em:

<http://cnj.jus.br/dpj/cji/bitstream/26501/1402/1/Tese_O\%20tr\%C3\%A1fic o\%20de\%20pessoas \%20em\%20tr\%C3\%AAs\%20dimens\%C3\%B5es.pdf

>. Acesso em: 12 março 2012.

CASTILHO, Ela Wiecko V. Tráfico de pessoas: da Convenção de Genebra ao Protocolo de Palermo. Disponível em: < http://pfdc.pgr.mpf.gov.br/atuacao-e-conteudos-deapoio/publicacoes/trafico-de-pessoas/artigo_trafico_de_pessoas.pdf $>$.

Acesso em: 03 junho 2012.

CEDAW. General Recommendation No. 19 (llth session, 1992). Disponível em:

http://www.un.org/womenwatch/daw/cedaw/recommendations/recomm.htm >. Acesso em: 04 outubro 2012.

- Concluding observations of the Committee on the Elimination of Discrimination against Women. CEDAW/C/ARM/CO/4/Rev.1. Disponível em:< http://daccess-ddsny.un.org/doc/UNDOC/GEN/N09/229/31/PDF/N0922931.pdf?OpenEleme nt>. Acesso em: 04 outubro 2012

LEAL, Maria Lúcia; LEAL, Maria de Fátima. Enfrentamento do tráfico de pessoas: uma questão possível? p. 30. Disponível em: <http://bvsms.saude.gov.br/bvs/publicacoes/politica_enfrentamento_trafico _pessoas.pdf>. Acesso em 11 setembro 2012.

SKINNER, Robyn; MAHER, Catherine. Child Trafficking and Organized Crime. Where Have All the Young Girls Gone? p. 4. Disponível em: < http://www.yapi.org/rpchildtrafficking.pdf>. Acesso em: 07outubro 2012.

ORGANIZAÇÃO DAS NAÇÕES UNIDAS. Notícia de 26 de março de 2007.

Disponível

em: 
$<$ http://www.un.org/apps/news/story.asp?NewsID=22009>. Acesso em 29 maio 2012.

- Notícia de 11 de outubro de 2010. Disponível em: < http://www.unhcr.org/4cb315c96.html>. Acesso em 5 novembro 2012.

Escritório das Nações Unidas sobre Drogas e Crime. Notícia de 03 de abril de 2012. Disponível em:

<http://www.unodc.org/unodc/en/frontpage/2012/April/un-generalassembly-president-calls-for-re-doubled-efforts-to-end-humantrafficking.html?ref=fs1>. Acesso em 20 maio 2012.

- Escritório das Nações Unidas sobre Drogas e Crime. International Framework for Action: to Implement the Trafficking in Persons Protocol. Disponível em: $<$ http://www.unodc.org/documents/humantrafficking/Framework_for_Action_TIP.pdf>. Acesso em 11 setembro 2012.

Economic and Social Council. Integration of the human rights of women and the gender perspective: violence against women .The due diligence standard as a tool for the elimination of violence aginst women. Disponivel em: < http://www.coe.int/t/dg2/equality/domesticviolencecampaign/Source/PDF _UN_Sp_Rapp_report_due_diligence_standard.pdf >. Acesso em 27 outubro 2012.

. Economic and Social Council. Report of the Special Rapporteur on violence against women, its causes and consequences, Ms. Radhika Coomaraswamy, on trafficking in women, women's migration and violence against women, submitted in accordance with Commission on Human Rights resolution 1997/44E/CN.4/2000/68 
2000.

Disponível

em:

http://www.unhchr.ch/Huridocda/Huridoca.nsf/0/e29d45a105cd814380256

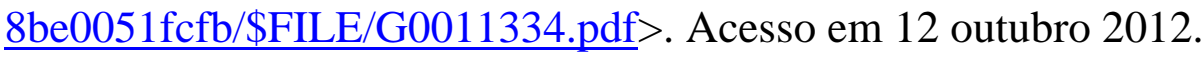

. Human Rights Council. Trafficking in persons, especially women and children. Resolution 11/3. Eleventh Session. Disponível em: < http://www.un.org/womenwatch/daw/vaw/humanrights/A_HRC RES 11 3.pdf>. Acesso em 14 outubro 2012.

. Human Rights Committee (HRC). CCPR General Comment No. 27: Article 12 (Freedom of Movement), 2 November 1999, CCPR/C/21/Rev.1/Add.9. Disponível em: <http://www.unhcr.org/refworld/pdfid/45139c394.pdf $>$. Acesso em: 29 agosto 2012 .

Assembleia Geral. Informe de la Relatora Especial sobre la venta de niños, la prostitución infantil y la utilización de niños en la pornografia. A/65/221. 4 de agosto de 2010. Disponível em <http://www.ungift.org/doc/knowledgehub/doc/knowledgehub/OHCHR/O HCHR_Special_Rapporteur_on_the_sale_of_children_General_Assembly_ spanish.pdf>. Acesso em: 27 agosto 2012

2004 World Survey on the role of women in development. A/59/287/Add.1 ST/ESA/294. New York, 2006. Disponível em: <http://www.un.org/womenwatch/daw/public/WorldSurvey2004-

Women\&Migration.pdf>. Acesso em:04 outubro 2012.

Draft articles on Responsibility of States for Internationally Wrongful Acts, with commentaries. Disponível em: < $\underline{\text { http://untreaty.un.org/ilc/texts/instruments/english/commentaries/9_6_200 }}$ 1.pdf>. Acesso em: 19 julho 2012. 
- Princípios e Diretrizes Recomendadas pelas Nações Unidas sobre Direitos Humanos e Tráfico de Pessoas. Disponível em: < http://www1.umn.edu/humanrts/instree/traffickingGuidelinesHCHR.html\#\# 7>. Acesso em: 04 outubro 2012. . Guia Legislativo para a aplicação da Convenção das Nações Unidas contra o Crime Organizado Transnacional $e$ seus Protocolos.Disponível em: <http://www.unodc.org/pdf/crime/legislative_guides/03\%20Legislative\%20 guide_Trafficking\%20in\%20Persons\%20Protocol.pdf >. Acesso em: 29 agosto 2012

\section{Instrumentos normativos}

BRASIL. Decreto n. 5.017, de 12 de março de 2004. Promulga o Protocolo Adicional à Convenção das Nações Unidas contra o Crime Organizado Transnacional Relativo à Prevenção, Repressão e Punição do Tráfico de Pessoas, em Especial Mulheres e Crianças. Disponível em: < http://www.planalto.gov.br/ccivil_03/_ato20042006/2004/decreto/d5017.htm >. Acesso em 11 setembro 2012.

. Decreto n. 5.015, de 12 de março de 2004. Promulga a Convenção das Nações Unidas contra o Crime Organizado Transnacional. Disponível em: <http://www.planalto.gov.br/ccivil_03/_ato20042006/2004/decreto/d5015.htm >. Acesso em 04 outubro 2012.

CONSELHO EUROPEU. Convenção sobre a Luta contra o Tráfico de Seres Humanos. Disponível em: < http://conventions.coe.int/Treaty/EN/Treaties/Html/197.htm>. Acesso em: 03 outubro 2012.

ORGANIZAÇÃO DAS NAÇÕES UNIDAS. Convenção sobre os Direitos da Criança. Disponível em: 〈http://www2.ohchr.org/english/law/crc.htm〉 Acesso em: 17 outubro 2012. 
- Protocolo Facultativo para Convenção sobre os Direitos da Criança relativo à venda de crianças, prostituição e pornografia infantis.Disponível em: $<$ http://www.unicef.org/brazil/pt/resources 10123.htm>. Acesso em: 04 outubro 2012.

. Convenção das Nações Unidas contra a Corrupção. Disponível em: < http://www.unodc.org/pdf/brazil/ConvONUcorrup_port.pdf $>$. Acesso em: 04 outubro 2012.

ORGANIZAÇÃOS DOS ESTADOS AMERICANOS. Convenção Interamericana sobre Tráfico Internacional de Menores. Disponível em: 〈http://www.oas.org/juridico/portuguese/treaties/B-57.htm>. Acesso em: 04 outubro 2012.

\section{Jurisprudência e Opinião Consultiva}

CORTE EDH. Caso Rantsev v. Cyprus and Russia. Sentença de 7 de janeiro de 2010.

CORTE IDH. Caso Velásquez Rodríguez vs. Honduras. Sentença de 29 de julho de 1988.

Corte IDH. Opinión Consultiva OC-16/99 de 1 de octubre de 1999. El Derecho a la Información sobre la Asistencia Consular en el Marco de las Garantías del Debido Proceso Legal. Serie A No. 16. 